$11-1-1996$

\title{
Reviving the Rhetoric of the Public Interest: Choir Directors, Copy Machines, and New Arrangements of Public Domain Music
}

\author{
Paul J. Heald \\ University of Georgia School of Law, heald@uga.edu
}

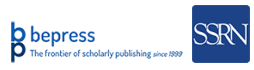

\section{Repository Citation}

Paul J. Heald, Reviving the Rhetoric of the Public Interest: Choir Directors, Copy Machines, and New Arrangements of Public Domain Music (1996),

Available at: https://digitalcommons.law.uga.edu/fac_artchop/375

This Article is brought to you for free and open access by the Faculty Scholarship at Digital Commons @ University of Georgia School of Law. It has been accepted for inclusion in Scholarly Works by an authorized administrator of Digital Commons @ University of Georgia School of Law. Please share how you have benefited from this access For more information, please contact tstriepe@uga.edu. 


\title{
REVIVING THE RHETORIC OF THE PUBLIC INTEREST: CHOIR DIRECTORS, COPY MACHINES, AND NEW ARRANGEMENTS OF PUBLIC DOMAIN MUSIC
}

\author{
PAUL J. HEALD ${ }^{\dagger}$
}

\section{INTRODUCTION}

Professor Peter Jaszi recently issued a challenge to those concerned about growing threats to the public domain. ${ }^{1}$ According to Jaszi, advocates of a broadly accessible and easily usable public domain must develop a new rlietoric by exploring alternative ways of speaking about the values they espouse. ${ }^{2}$ It is time for such a challenge-arch-protectiomists are on the march, determined to recapture works from the public doinain for their private benefit, ${ }^{3}$

† Baritone, Saint Gregory the Great Episcopal Church Choir, Athens, Georgia. Associate Professor of Law, University of Georgia School of Law. J.D., 1988, University of Chicago. Many thanks to my musically talented friends Jill Crandall, Kevin Kelly, Chuck Beaudrot, Esq., and Mark Schweizer, and to Jim Brinson, Director of the 45th Annual Sewanee Church Music conference, for letting me present a version of this paper to an audience of choir directors whose comments were invaluable. Thanks also for the insightful comments of those whose professional lives revolve around the law: Wendy Gordon, Chris Kelly, Jessica Litnan, Shira Perlmutter, David Seidman, David Wolfsohn, Esq., D.M.A., and Fred Yen.

1. See Peter A. Jaszi, Goodbye to All That-A Reluctant (and Perhaps Premature) Adieu to a Constitutionally-Grounded Discourse of Public Interest in Copyright Law, Address at the American Association of Law Schools Annual Convention (Jan. 7, 1996), in 29 VAND. J. TRANSNAT'L L. 595 (1996). Professor Jaszi specifically mentioned as a threat recent legislation restoring copyright protection to certain foreign works, thus renoving thein from the public domain. See id. at 606-07 (discussing 17 U.S.C. $\S 104 \mathrm{~A}(\mathrm{~g})$ (1994)).

2. Jaszi concludes that "defenders of the public interest must begin to develop evidence and argnnents that function, at least to some extent, independently of the specific terns of the Patent and Copyright Clause, and carry on the work of explaining why and to whoin the public domain matters." Id. at 611.

3. For evidence of this trend, see 17 U.S.C. $\S 104 \mathrm{~A}(\mathrm{~g}) ; 17$ U.S.C. $\S 302(\mathrm{a})$, (c) (1976) (extending the term of copyright froin 28 years with a 28-year renewal right, to the life of the author plus 50 years). Proposed legislation would further extend protection to the life of the author plus 70 years. See Songwriters Want Copyright in Tune with Laws Overseas; Adding 20 Years Would Bolster Economy, Backers Say, WASH. TMME, Nov. 1, 1995, at A2. Advocates of consumer interests have combined forces to fight 
and the old ways of advocating the public interest can no longer be counted on to carry the day. The public has demonstrated little understanding of the nature of the public domain and, unlike the publishing industry, has shown little ability to effectively protect its interest. As a remedy, Jaszi suggests that scholarly commentators bear the burden of explaining why the public domain is so important. ${ }^{4}$

Several perceptive explorations of the public domain have already appeared..$^{5}$ Although these articles provide a theoretical framework for protecting the public domain, a focus on the particular rather than the general might better effect the rhetorical move proposed by Jaszi. Given "the natural tendency of legal rights to express themselves in absolute terms to the exclusion of all else," perhaps the best way to defend the public domain is to demonstrate its particular importance to those who draw from it. To this end, we will enter the world of the choir director and conduct a case study in the public domain.

A confused choir director recently showed me a version of the William Billings anthem "Jordan" published in $1954,{ }^{7}$ pointed to the bottom of the page, and asked me low the work of a composer who has been dead for almost 200 years could remain copy-

certain aspects of the Clinton Administration's "White Paper," a policy statement on intellectual property and the Internet written by the National Information Infrastructure Task Force Working Group on Intellectual Property Rights. The White Paper is widely viewed as advocating the expansion of the current scope of copyright protection in favor of publishers. For a discussion, see Pamela Samuelson, Intellectual Property Rights and the Global Information Economy, 39 COMM. OF THE ACM 23, 24 (1996) ("[I]f the public can be brought to understand how substantial a change is being sought, the White Paper inay get the quick funeral it deserves.").

4. Professors who teach copyright law have recently collaborated on a series of amicus briefs in major copyright cases and have consistently taken the side of the consumer, the copier, and the public interest against that of well-organized corporate enterprises. See, e.g., Pamela Samuelson, Brief Amicus Curiae of Copyright Law Professors in Lotus Developinent Corp. v. Borland Int'l, Inc., 3 J. INTELL. PROP. L. 103 (1995) (reprinting amicus brief in support of respondent in the Borland case, $116 \mathrm{~S}$. Ct. 804 (1996)).

5. See, e.g., Keith Aoki, Authors, Inventors and Trademark Owners: Private Intellectual Property and the Public Domain (pts. 1 \& 2), 18 CoLUM.-VLA J.L. \& ARTS 1, 191 (1994-95); Wendy J. Gordon, A Property Right in Self-Expression: Equality and Individualism in the Natural Law of Intellectual Property, 102 YALE L.J. 1533 (1993); Jessica Litman, The Public Domain, 39 EMORY LJ. 965 (1990).

6. Sony Corp. of America v. Universal City Studios, Inc., 464 U.S. 417, 432 n.13 (1984) (commenting on intellectual property rights and rejecting the expansion of copyright hability for video piracy to sellers of VCRs).

7. Reproduced as Appendix B2. 
righted. ${ }^{8}$ A glance at the sheet music revealed a copyright symbol. My snappy and not entirely helpful answer was that a sufficiently original arrangement or edition of a public domain composition is entitled to protection by copyright law. ${ }^{9}$ She then presented me with a copy of the original version of "Jordan," long in the public domain, and asked me to identify the differences between the two works. ${ }^{11}$ Her critical follow-up question: could she photocopy the 1954 publication and distribute it to lier choir? In other words, did the copyright symbol on the piece have any legal force? While lier question in the case of "Jordan" was academic (since the public doinain work was in her other hand), the legal status of recent versions of public domain inusic is, $\mathrm{m}$ general, extremely important to choir directors: original versions of the music they seek are usually very difficult to obtain. ${ }^{12}$

Although most published opimions discussing arrangements of public domain music suggest that the 1954 publication of "Jordan" is not sufficiently original to be protected by copyright, and therefore is probably annenable to the photocopy machine, the parameters of the apphicable legal standard are hazy. ${ }^{13} \mathrm{~A}$ recent case finds that, to be protected by copyright, a new arrangement of pre-existing work inust contain more than "cocktail pianist variations .... [S]omething of substance [must be] added making the piece to some extent a new work with the old song embedded in it." 14 Another, older case holds that "imconsequential inelodic and

8. William Billings (1746-1800) was one of first great American composers of choral music. His works remain popular today. See THE EPISCOPAL CHURCH, THE HYMNAL 1982: 2 HYMNS ACCOMPANIMENT EDIMION (1985). The publication of his complete works in 1986 marked the first edition of the complete works of any American composer. See James Haar, Forward to 1 THE COMPLETE WORKS of WILLIAM BILLINGS at ix (Karl Kroeger ed., 1986).

9. A musical arrangement is a "derivative work." See 17 U.S.C. $\S 101$ (1994). An original derivative work is copyrightable. See id. $\S 103$. The standard of originality required is discussed infra notes $61-81$ and accompanying text. All works published more than 75 years ago are considered to be in the public domain and may be copied by anyone without the permission of the author or her estate. See 17 U.S.C. $\$ \$ 304(a)(1)(A)$ (1994). For a discussion of music and the public domain, see M. WILLIAM KRASILOVSKY \& SIDNEY SHEMEL, THIS BUSINESS OF MUSIC 259-67 (7th ed. 1995).

10. See Appendix B1. The piece was first pubhished in 1786. See 3 THE COMPLETE WORKS OF WILLIAM BIILINGS, supra note 8 , at 137, and infra notes 140-46 and accompanying text.

11. Compare Appendix B1 with Appendix B2.

12. See infra notes $172-78$ and accompanying text.

13. See infra notes $61-81$ and accompanying text.

14. Woods v. Boume Co., 841 F. Supp. 118, 121 (S.D.N.Y. 1994) [hereinafter Woods 
harmonic embellishments such as are frequently improvised by any competent musician" are not sufficiently original to earn copyright protection for an arrangenient of a public domain work. ${ }^{15}$ Another opinion suggests, however, that the addition of new "fingering, dynamic nıarks, tenıpo indications, slurs and phrasing" can be enougli. ${ }^{16}$

None of the cases that discuss this issue provide an appendix that allows the reader to compare the public doinain version of a composition with the allegedly original, derivative arrangement. The articulated tests, described as the "n1ere nuechanic" test, ${ }^{17}$ the "substantiality" test, ${ }^{18}$ and the "distinguisliable variation" test, ${ }^{19}$ are too vague in and of theinselves to resolve disputes. The lack of visual coniparisons and the limited precedential value of the relevant opimons ${ }^{20}$ coniplicates the clioir director's determination of whether she can photocopy an arrangenient of public doinain nuusic or nuust purchase multiple copies of the work.

The decision to photocopy or not to pliotocopy lias significant consequences for the music consumer's pocketbook. Photocopies

n] (holding that seven arrangements of "When the Red, Red Robin Comes Bob-BobBobbin' Along" were not sufficiently original derivative works to be immune from an attempt by the composer's estate to exercise the $\S 304$ (17 U.S.C.) termination right), affd in part and rev'd in part, Woods v. Bourne Co., 60 F.3d 978, 991 (2d Cir. 1995) [hereinafter Woods II]. The court assumed, as does this Article, that the same standard should be used to judge the originality of public domain compositions and arrangements of protected music. See id. at $990-93$.

15. See McIntyre v. Double-A Music Corp., 166 F. Supp. 681, 683 (S.D. Cal. 1958).

16. Consolidated Music Publishers, Inc. v. Ashley Publications, Inc., 197 F. Supp. 17, 18 (S.D.N.Y. 1961).

17. See Ronald P. Smith, Arrangements and Editions of Public Domain Music: Originality in a Finite System, 34 CASE W. RES. L. REv. 104, 108-14 (1983) (noting cases that deny protection to arrangements derived by the mechanical application of general music principles). See id. at 111 (classifying McIntyre, 166 F. Supp. 681, as a "mere mechanic" case). Woods $I I$ also applies this test, emphasizing that "the requirement of originality [cannot] be satisfied simply by the denonstration of "physical skill" or "special training."' " 60 F.3d at 990 (quoting L. Batlin \& Son, Inc. v. Snyder, 536 F.2d 486, 491 (2d Cir. 1976) (en banc)).

18. See Smith, supra note 17 , at $115-20$ (identifying opinions that require a "substantial" difference between the original and the arrangement) (citing Wood v. Boosey, 3 L.R.-Q.B. 223, 230 (1868) (piano reduction of operatic score contained enough substantial differences to be a "new and separate work")).

19. See id. at 122 (noting that some cases require that "derivations of public domain works need only represent a 'distingrishable variation' to warrant protection") (citing Plymouth Music Co. v. Magnus Organ Corp., 456 F. Supp. 676 (S.D.N.Y. 1978)). Consolidated Music, see supra note 16 and accompanying text, would probably fall in this group.

20. Almost all the decisions are from federal district courts. See, e.g., supra notes 14$16,19$. 
cost around three cents per page, ${ }^{21}$ while an original printed version of a choral work costs about thirty cents per page. ${ }^{22}$ The expense of buying rather than copying public domain sheet music is directly absorbed by the taxpayers who fund music education in public schools, the church congregations who must raise money for the church music budget, and the patrons of the fine arts who finance music ensembles with their admission fees or donations. ${ }^{23}$

To recognize the high cost of sheet music is not to assert that legitimately registered works slould be pirated at the copy machine. The point is that the decision to purchase rather than to photocopy is a costly one, that as consumers, taxpayers, and churchgoers we are directly affected when the decision to purchase is made unnecessarily. Arrangements of public doinain music not sufficiently original to be protected by copyright law are free to all, ${ }^{24}$ yet, much to our financial detriment, the law does not sufficiently identify exactly which of these arrangements are fair game.

Music publishers, taking advantage of this uncertainty, intimidate the public into buying what they already own by affixing copyright symbols to virtually all public domam music as well as trivially different arrangeinents of public domain music. ${ }^{25}$ Publishers

change titles without modifying lyrics or melody. They may claim full originality when they are really only "finders" of public do-

21. Telephone Interview with Annette Hicks, Parish Administrator, Saint Gregory the Great Episcopal Church, Athens, GA (Nov. 27, 1996). In Athens, McCopy's currently charges four cents per page.

22. This estimate based on an informal survey of anthems offered for sale by Vester Music at the 45th Annual Sewanee Church Music Conference, July 9-16, 1995.

23. For an illustration from just one relevant market, assume that 100,000 twentymember church choirs in the United States sing at least six public domain arrangements per year and the average length of each work is five pages. The decision to buy new sheet music for those performances $(100,000$ choirs $\times 20$ choristers $\times 6$ anthems $\times 5$ pages $\times \$ .30$ (cost of each piece of sheet music) $=\$ 18$ million) as opposed to photocopying $(100,000 \times 20 \times 6 \times 5 \times \$ .03$ (copy cost) $=\$ 1.8$ million) implicates a substantial sum ( $\$ 16.2$ million), all of which comes at the expense of other church programs. Given that far more than 100,000 churches have choirs of more than twenty (nailing addresses collected in a database sold by American Church U.S.A. list more than 345,000 churches in the United States), and given the popularity of public domain church music by Bach, Brahms, Billings, etc. (to name just some of the B's), $\$ 16.2$ million would seem to be a gross underestimation. And this figure does not take into acconnt taxpayers' money spent to finance public performances by private groups or on sheet music for music programs in the millions of public educational institutions around the country.

24. See, e.g., Appendices A2, B2, and C2.

25. See id. 
main songs. They register copyrights to such songs, claiming they are "original" works, and fail to set forth accurately the limited amount of any new material. They thereby falsely and unfairly obtain the benefit of the Copyright Act provision that places on an unauthorized user the burden to prove the invalidity of a certificate of copyright registration. ${ }^{26}$

This Article, in response to Professor Jaszi's challenge, uses the particular experience of a choir director and visual comparisons of public domain and "copyrighted" works to inquire into the standard that governs the copyrightability of musical arrangements and, at the saine time, to strengthen the voice of the public domain.

\section{Theoretical Preliminaries AND INTRODUCTION TO THE RELEVANT LAW}

The law governing arrangements of public domam music can perhaps be explained best in hight of the policies that animate the Copyriglit Act.

\section{A. The Copyright Bargain: Lessons from History and Some Eco- nomic Theory}

The Copyright Clause of the Constitution ${ }^{27}$ einbodies a hypothetical bargain struck between the polity and its artists: citizens give artists the right to exclude others from copying their creations, in return for free use of those creations after the expiration of a set time. ${ }^{28}$ England's experience under the Stationer's Company publishing monopoly, ${ }^{29}$ which led to copyright reform under

26. KRASILOVSKY \& SHEMEL, supra note 9, at 251-52.

27. U.S. Const. art. I, \& 8, cl. 8 ("Congress shall have Power ... [t]o promote the Progress of . . . useful Arts, by securing for limited Times to Authors ... the exclusive Right to their respective Writings").

28. See Sony Corp. of America v. Universal City Studios, Inc., 464 U.S. 417, 429 (1984) (Copyright law "is intended to motivate the creative activity of authors and inventors by the provision of a special reward, and to allow the public access to the products of their genius after the limited period of exclusive control has expired."); see also Mazer v. Stein, 347 U.S. 201, 219 (1954) (explaining that the granting of a copyright is intended to encourage individual effort by personal gain in an attempt to advance public welfare); KRASILOVSKY \& SHEMEL, supra note 9, at 261-62 (discussing the justifications for a temporal limitation). Works currently fall into the public domain 50 years after the death of the author. See 17 U.S.C. § 302 (1994).

29. For an examination of this experience, see L. RAY PATTERSON \& STANLEY W. LINDBERG, THE NATURE OF COPYRIGHT 23-27 (1991) (explaining that the self-interest of 
the Statute of Anne, ${ }^{30}$ was not a lesson lost on the Framers of the Constitution. ${ }^{31}$ They knew that the grant of exclusive rights would be a cost borne directly by the public, and they demanded a direct public benefit in return. ${ }^{32}$ In theory, the possibility of obtaining a valuable monopoly provides economic imcentives for the creation of new works which would eventually be dedicated to the public domain. ${ }^{33}$ For this reason, the first Congress promptly used its constitutional authorization and provided protection for maps, charts, and books in $1790 .^{34}$

Works in the public domam at the time of the ratification of the Constitution (all of the works of J.S. Bach, for example), remaimed (and remaim) free for all to use. Granting someone an

copyright owners combined well with governmental interests to make copyright an ideal "instrument of censorship" in seventeenth century England).

30. 8 Anne, ch. 21 (1719) (Eng.). See generally Lyman Ray Patterson, The Statute of Anne: Copyright Misconstrued, 3 HARV. J. ON LEGIS. 223, 225 (1966) (explaining that the Statute of Anne modified prior British copyright law by extending copyright protection to anyone complying with the statute (not just members of the book trade), and by limiting copyright protection to a term of years). In opposing legislation offered in the nineteenth century to extend the duration of copyright protection, English historian Thomas Macaulay argued that "[f]or the sake of the good we must submit to the evil [of copyright protection]; but the evil ouglit not to last a day longer than is necessary for the purpose of securing the good." Thomas Macaulay, Speech Before the House of Commons (Feb. 5, 1841), in 8 THE WORKS OF LORD MACAULAY 195, 199 (Lady Hannah More (Macaulay) Trevelyan ed., 1866), cited in Wendy J. Gordon, An Inquiry into the Merits of Copyright: The Challenges of Consistency, Consent, and Encouragement Theory, 41 STAN. L. REV. 1343, 1344 (1989).

31. See L. Ray Patterson \& Craig Joyce, Monopolizing the Law: The Scope of Copyright Protection for Law Reports and Statutory Compilations, 36 UCLA L. REV. 719, 785-86 (1989) (explaining that the significance of copyright in this period of English history "was not unknown in eighteenth century America because of the importance attached to the freedom of the press, speech and religion, as demonstrated by the adoption of the First Amendment"); see also Paul J. Heald, The Vices of Originality, 1991 SUP. CT. REv. 143, 173-74 ("[The Framers] wanted the Intellectual Property Clause to prevent abuses like those perpetrated when the Stationer's Company exercised complete control over publishing in England.").

32. See Heald, supra note 31 , at 174.

33. See William W. Fisher III, Reconstructing the Fair Use Doctrine, 101 HARV. L. REV. 1659, 1687 (1988); see generally Williain M. Landes \& Richard A. Posner, An Economic Analysis of Copyright Law, 18 J. LEGAL STUD. 325 (1989) (discussing how to strike an appropriate balance between access and incentives in copyright law based on the principles of efficient resource allocation). Cogent arguments can be made that the economic rationale for copyright is imcomplete. See Gordon, supra note 30, at 1435-58 (noting that economists "have as yet offered no full-scale philosophic defense for their position that individual desert should be irrelevant to the allocation of intellectual property rights").

34. Act of May 31,1790 , ch. 15, 1 Stat. 124-26. 
exclusive right to a Bach Cantata would impose a cost on the public without any countervailing benefit. Since the ratification of the Constitution, Congress has with increasing aggressiveness established a system of rewards and incentives for artists. ${ }^{35}$ Nobody can prove that artists are nore productive because of copyright law, but if they have been, the payoff has been spectacular. ${ }^{36}$ Consider the vast wealth of musical, literary, and other artistic works that now belong to the public-everything published before $1921,{ }^{37}$ and even soine created thereafter. ${ }^{38}$

Congress has always recognized the public's proprietary interest in the public doinain. For example, nothing in an arrangement of a public doinain music coinposition is protected unless it quahfies as a "derivative work" which consists of "editorial revisions, annotations, elaborations, or other inodifications which, as a whole, represent an original work of authorship." 39 Even if a coinposer creates an original arrangeinent of a public doinain work, the new copyright "extends only to the inaterial contributed by the author of such work, as distinguished froin the preexisting inaterial.".40 For example, only an original bass line added to a public doinain coinposition would be protected by copyright. In $L$. Batlin \& Son, Inc. v. Snyder, ${ }^{41}$ the Second Circuit provided a clear explanation why:

Absent a genuine difference between the underlying work of art and the copy of it for which protection is sought, the public interest in promoting progress in the arts-indeed, the constitutional demand . . . could hardly be served. To extend copyright-

35. Compare 17 U.S.C. $\S 102$ (1994) with 17 U.S.C. $\S 102$ (1977) (mentioning no explicit copyright protection for "architectural works").

36. But see Steplen Breyer, The Uneasy Case for Copyright: A Study of Copyright in Books, Photocopies, and Computer Programs, 84 HARV. L. Rev. 281, 351 (1970) ("[C]opyright is very much of a mixed blessing. It can lead to prices higher than necessary to secure production ... [and] can impose large transactions costs . . . .").

37. See supra note 9.

38. Under the Copyright Act of 1909 , ch. 320, 35 Stat. 1075 (1909), the failure to renew a copyright after 28 years of registration put many works published after 1920 and before 1964 into the public domain. See La Cienega Music Co. v. ZZ Top, 44 F.3d 813, 814-15 (9th Cir. 1995).

39. 17 U.S.C. \& 101 (1994).

40. Id. \& 103(b). See also U.S. COPYRIGHT OFFICE, LIBRARY OF CONGRESS, CIRCULAR No. 14 (1995) ("Making minor changes or additions of little substance to a preexisting work will not qualify the work as a new version for copyriglit purposes.").

41. 536 F.2d 486, 492 (2d Cir. 1976) (en banc) (holding copyright of plaintiff's version of "Uncle Sam" bank invalid because bank was not substantially original). 
ability to minuscule variations would simply put a weapon for harassment in the hands of mischievous copiers intent on appropriating and monopolizing public donain work. ${ }^{42}$

In other words, the public should not have to pay a monopoly price for a work that is essentially the same as its public domain progenitor.

In addition, keeping the public domam free for exploitation makes economic sense. A musical work, like a lighthouse or a new word is a "public good." That is to say, each successive use of it does not diminish its intrinsic value. ${ }^{43}$ Unlike a piece of land that is farmed or a car that is driven, no matter how many times a piece of music is performed, it does not wear out. No matter how many copies of a musical conposition are made, still more can be made equally cheaply. In theory, once a public good is created, charging consumers to use it entails a deadweight loss. ${ }^{44}$ Limiting its use serves no purpose, since each successive use does not harm it. A composition is not like a lake full of fish whose exploitation must be limited to maintain its stock.

Nonetheless, under soine circumstances it may be appropriate to charge consumers of public goods. It may be rational to grant their creators exclusive riglits for fear that, absent a monetary incentive allowing for the recovery of sunk costs, some public goods will not be created in the first place. ${ }^{45}$ In theory, for example, some music may not be written in the absence of the monetary incentives provided by copyright law. ${ }^{46}$ This rationale, of course, has no application to works that have already been created, such as our vast supply of public domam compositions. We may need incentives for music to be written tolnorrow, but not for music written seventy-five years ago.

42. Id.

43. See ARMEN A. Alchian \& William R. Allen, Exchange and Production THEORY IN USE 251-53 (1969), reprinted in EDMUND W. KTTCH \& HARVEY S. PERLMAN, LEgal REgUlation OF the COMPETITIVE PROCESS $47-49$ (4th rev, ed. 1991).

44. See id. at 48 (noting that "once the lighthouse is built, exclusion of anyone could be wasteful").

45. See id. But see Gordon, supra note 30, at 1439 ("Sole reliance on the wealthmaximizing criterion to grant or deny copyright is highly questionable."). Gordon suggests "individual desert" is relevant as a non-encouragement-based theory to explain copyright. Id. at 1447.

46. See supra text accompanying notes $28-34$. 
The copyright bargain, whether one views it in economic terms or as the binding intent of the Framers of the Constitution, should and does extend to original derivative works. No one believes, for example, that Aaron Copland's "Appalachian Spring" should be uncopyrightable because it borrows one of its theines from the old Shaker hymn "Simiple Gifts," a piece long in the public domain. ${ }^{47}$ Similarly, the Electric Light Orchestra's "Roll Over Beethoven" is properly copyrighted in spite of the incorporation of bits of Beethoven's Fifth Symphony. ${ }^{48}$ Congress has provided incentives for composers to mine the public domain and create original new works. In theory, we would have fewer such works in the absence of protection. Given the inportance of the public domain as an inspiration for new creations, ${ }^{49}$ Congress has rationally included original derivative works as a category of copyrightable expression. ${ }^{50}$

Congress has also just as rationally excluded "unoriginal" variations of public domain works froin protection, ${ }^{51}$ thereby disarming those who may attempt to obtam a "weapon for harassment" by copyrighting works with only minor changes. ${ }^{52}$ In this regard, the Court has defined "original" in such a way as to preclude protection based merely on a work's intrinsic value or the amount of labor necessary to create it. In Feist Publications, Inc. v. Rural Telephone Service Co. ${ }^{53}$ the Court demied copyright protection to the telephone white pages, einphasizing that the Constitutional requirement of authorship ${ }^{54}$ precluded protection of unoriginal works. ${ }^{55}$ The compilers of the white pages expended substantial effort in creating a very valuable new work, but that was not enough. Under the rationale of Feist, a court would be forced to conclude that the cost to the public of granting an arranger or an editor of public domain music a monopoly is not offset by any countervailing public benefit when the new work is essentially the

\footnotetext{
47. See Smith, supra note 17 , at 125 n.146.

48. Hear also Paul Simon's "American Tune," which borrows directly from the main chorale of Bach's "St. Matthew's Passion."

49. Some have even argued that virtually all new works are inescapably based on public domain materials. See Litinan, supra note 5, at 966-67, 1007-11.

50. See 17 U.S.C. \$\$ 101, 103(a) (1994).

51. See id. \& 103(b) (1994).

52. See L. Batlin \& Son, Inc. v. Synder, 536 F.2d 486, 492 (2d Cir. 1976) (en banc).

53. 499 U.S. 340 (1991).

54. See id. at 344-61; see also supra note 27 .

55. See Feist, 499 U.S. at 351.
} 
same as the original. While new editions of old music are often useful and valuable, as a matter of constitutional law, Congress cannot grant copyright protection to unoriginal works no matter how much sweat has been expended in their creation. ${ }^{56} \mathrm{~A}$ new but unoriginal typesetting and printing of a Billings anthem may be useful and valuable, but it is not protected by copyright law. ${ }^{57}$

I have elsewhere argued that Feist's disavowal of copyright protection for "sweat of the brow" works may be inconsistent with the copyright bargain described above, noting that some valuable, but unoriginal, works may not be created in the absence of copyright incentives. ${ }^{58}$ If, as the economists suggest, copyright is about establishing wealth-maximizing mcentives to bring about new creations, then Feist's affirmation of a Romantic notion of authorship may be misplaced. For example, Handel's "Messiah" is a public domam work, but Congress might rationally conclude that limited copyright protection for new editions of the "Messiah" are needed to ensure that the public's demand is satisfied. The Court in Feist prevents Congress from acting on such a conclusion. To this extent, the case strays from a purely economic justification for copyright, while expressly endorsing it. ${ }^{59}$ Although I seriously doubt that legislation is necessary to stimulate new editions of public domam music, ${ }^{60}$ Feist's rationale probably precludes it.

56. See Heald, supra note 31, at 168-75 (arguing that Congress could not use its power to regulate interstate commerce to grant copyright-like protection to unoriginal expression).

57. See infra text accompanying notes 89-94.

58. See Heald, supra note 31, at 158-59 (stating that Feist frustrates Congress from "conducting a direct inquiry into whether protecting a particular type of work from a particular type of borrowing is necessary to promote the public welfare").

59. See Feist, 499 U.S. at 358 ("[W] conclude that [the Copyright Act of 1976, 17 U.S.C. § 102 (1976)] envisions that there will be some fact-based works in which the selection, coordination, and arrangement are not sufficiently original to trigger copyright protection.").

60. New music software should revolutionize the way in which the music publishing industry delivers music to consumers. Publishers will no longer be forced to estimate market demand before they decide to print a fixed number of copies of public domain sheet music they plan on selling. Technology exists that will allow the publishers to "call up" a piece of music on a database and then print only the number of copies that are actually ordered. The lowered cost of producing printed sheet mnsic should facilitate competition with the photocopy machine; technology will no doubt make public domain sheet music easier to acquire in the long run. 


\section{B. The Inadequate Caselaw}

Only one federal appellate decision in the last forty years discusses the standard of originality necessary for a new musical composition to constitute a copyrightable derivative work. In Woods v. Bourne Co., ${ }^{61}$ the Second Circuit held that several versions of "When the Red, Red, Robin Comes Bob, Bob, Bobbin' Along" were insufficiently original to constitute copyrightable derivative works. ${ }^{62}$ Although the opinion does not reprint the original song or subsequent versions of it, the court's discussion is helpril. In 1926, Harry Woods brought a "lead sheet," consisting of the melody and lyrics of the song, to Irving Berlin, Inc., whose in-house "technicians" then added harmony and made other changes. ${ }^{63}$ Finding the differences between Woods' lead sheet and the subsequent "piano-vocal" version that was eventually published to be insubstantial, the district court held the piano-vocal version to be unoriginal. ${ }^{64}$ It also found unoriginal a 1981 version of the song that substituted a moving bass line for the piano-vocal harinony, which had primarily consisted of quarter notes on the first and third beats of every measure. ${ }^{65}$

The Second Circuit affirmed both these holdings, approving the legal standard required by the district court:

[S]omething of substance [must be] added making the piece to some extent a new work with the old song embedded in it but

61. 60 F.3d 978 (2d Cir. 1995) (Woods II).

62. The issue of whether the versions of the song were derivative works was made relevant by 17 U.S.C. $\S 304(c)(1)-(3)$ (1994), which gives an author, or his heirs, the right to terminate an improvident assignment of copyright at the end of the renewal term. However, this termination right, along with the right to capture continuing royalties, does not extend to original derivations of the assigned copyrighted work prepared before the termination of the assignment. See Woods II, 60 F.3d at 986. For example, Woods' heirs terminated Woods' assignment of the copyright of the song at issue to the predecessor in interest of Bourne Music. Bourne argued that the versions of the song that continued to generate royalties for it were original derivative works and therefore immune from the heirs' claims. Thus, the right to the royalties tumed on whether the income-producing versions of the song were sufficiently original to constitute derivative works. In their rehiance on precedent involving arrangements of public domain musical works, the district court and the Second Circuit both presumed that the standard of originality for derivative musical works in the termination context is the same as that applied in the context of arrangenents of public domain music. See id. at 990-91.

63. See id. at $981,989,992$.

64. Woods I, 841 F. Supp. 118, 121 (S.D.N.Y. 1994), affd in part and rev'd in part, 60 F.3d 978 (2d Cir. 1995).

65. Woods II, 60 F.3d at 993. 
from which the new has developed. It is not merely a stylized version of the original song where a major artist may take liberties with the lyrics or the tempo, the listener hearing basically the original tune.... [C]ocktail piamist variations of the piece that are standard fare in the music trade by any competent musician [do not suffice]. ${ }^{66}$

The Second Circuit emphasized that a "trivial variation" from the first work or the mere "demonstration of 'physical skill' or 'special training" was not enough. ${ }^{67}$ Although the circuit court approved of the district court's factual inquiry into whether the piano-vocal arrangement was the result of the application of "conventional rules of harmony," that a derivative work must contain "unusual vocal treatment, additional lyrics of consequence, unusual altered harmonies, [and] novel sequential uses of themes. ${ }^{.69}$ Most importantly, the opinion recognizes the role played by a substantial originality standard in taking "'a weapon for harassment [from] the hands of mischievous copiers mtent on appropriating and monopolizing public domain work." $" 70$

Other decisions which discuss derivative musical arrangements are also quite sensitive to the danger that trivializing the originahty requirement would present to the public domam. They all demand a palpable contribution by the arranger; whether they apply precisely the same standard of originality, however, is difficult to discern. Without the actual pieces of music before us, it is virtually impossible to conclude whether the reported decisions are really consistent. For example, Northern Music Corp. v. King Record Distributing $\mathrm{Co}^{71}$ holds that "neither rhythm nor harmony can in itself be the subject of copyright," ${ }^{72}$ overtly conflicting with an-

66. Id. at 991 (quoting Woods $I, 841 \mathrm{~F}$. Supp. at 121).

67. Id. at 990 (citing L. Batlin \& Son, Inc. v. Snyder, 536 F.2d 486, 491 (2d Cir. 1976) (en banc)).

68. Id. at 992 .

69. Id. at 990 (quoting Woods I, $841 \mathrm{~F}$. Supp. at 121).

70. Id. (quoting Batlin, 536 F.2d at 492). The court also endorsed the Seventh Circuit's opinion in Gracen v. Bradford Exchange, 698 F.2d 300 (7th Cir. 1983) (mimetic painting of Dorothy taken from a scene of the motion picture The Wizard of $O z$ not an original derivative work), that "advised special caution in analyzing originality in derivative works, since too low a threshold will 'giv[e] the first [derivative work] creator a considerable power to interfere with the creation of subsequent derivative works from the same underlying work." Id. (quoting Gracen, $698 \mathrm{F.2d}$ at 305).

71. 105 F. Supp. 393, 400 (S.D.N.Y. 1952).

72. Id. at 400. The court also held that a composer's song was not rendered 
other decision from the same jurisdiction, Tempo Music, Inc. $v$. Famous Music Corp. ${ }^{73}$ which finds a Duke Ellington harmony protectable. $^{74}$ While these two opinions are hard to reconcile, even the Tempo court demonstrates an awareness of the danger of adopting a standard of originahty that would demand only a trivial variation from the pre-existing work. ${ }^{75}$ Unfortunately, neither of these opinions are discussed by the Second Circuit in Woods II, a frustrating state of affairs given that both cases arise in the Southern District of New York.

A relatively small number of other cases are relevant. The court in McIntyre v. Double-A Music Corp. ${ }^{76}$ refused to find origmakity in an arrangement that added an introduction, some repetition, and "inconsequential melodic and harmonic embellishments." In Wihtol v. Wells, ${ }^{78}$ the Seventh Circuit protected a hymn with new lyrics that borrowed from an old Latvian folk melody remembered from the composer's childhood. A very simple new bass line was found insufficiently original to be protected in Shapiro, Bernstein \& Co. v. Miracle Record Co. ${ }^{79}$

With the exception of Consolidated Music Publishers, Inc. v. Ashley Publications, Inc. ${ }^{80}$ which seems to hold several imsignificant editorial changes copyrightable ${ }^{81}$ the language and intent of the decisions are consistent with the copyright bargain discussed above. But while the cases do not conflict with the constitutional and statutory requirements of originality, they provide inadequate guidance to a consumer concerned with whether a particular arrangement is protected or not. The courts have not consciously protected insignificant arrangements or approved the "weapon for harassment" decried by the Second Circuit. However, the pub-

uncopyrightable simply by reason of his use of musical "sequences" employed by others. Id.

73. 838 F. Supp. 162 (S.D.N.Y. 1993).

74. See id. at 170-71 (finding jazz harmonies added by Duke Ellington to "Satin Doll" protected by copyright).

75. See id. at $169-70$.

76. 166 F. Supp. 681 (S.D. Cal. 1958).

77. Id. at 683 .

78. 231 F.2d 550, 553-54 (7th Cir. 1956).

79. 91 F. Supp. 473, 474 (N.D. Ill. 1950).

80. 197 F. Supp. 17, 18 (S.D.N.Y. 1961).

81. Without the music, it is not possible to determine the extent of the editing that the court describes. Perhaps it was so extensive that an original work was created. The court found that there was "at least a modicum of creative work" present and that this modicum was more than a "mere trivial variation." Id. 
lished decisions have also not thwarted attempts by music publishers to capture the public domain. These publishers, by affixing copyright symbols to public domain music and thereby intimidating music buyers, have managed to subvert copyright pohicy nonetheless.

\section{SPURIOUS ClAimS TO COPYRIGHT IN MUSICAL} ARRANGements: The Threat to PUblic DomaIn Music

I have elsewhere explored the causes of action which might be brought against a publisher who profits by improperly affixing a copyright symbol to a public domain work. ${ }^{82}$ I have not, however, previously detailed practices in the music publishing industry or provided guidance to those seeking to distinguish works in the public domain, which can be copied, from those that are protected, which can not. Appendices A1 to $\mathrm{C} 2$ to this Article provide examples of public domain works side-by-side with recently "copyrighted" versions, illustrating Krasilovsky and Sliemel's warning that "[m]uch of the music material in the pubhic domam is tainted by vague and indefinite claims of copyright in minimal or obscure 'new versions." "\$3

A well-known, one-page Brahms chorale for women's voices, "O bone Jesu," recently ordered from a national sheet inusic distributor for $\$ 1.60$ plus $\$ 2.80$ shipping and handling, appears as Appendix A2. ${ }^{84}$ At the bottoin of the page, one finds a copyriglit symbol and the statement "Copyright 1979 by Carus-Verlag Stuttgart." Undoubtedly, many choir directors and music educators would think twice about dehberately ignoring the registration symbol and would decide to purchase more copies of the one-page sheet music at $\$ 1.60$, rather than make their own copies for three cents apiece. Inducing reliance on the part of nusic buyers and intimidating them imto purchasing, rather than photocopying, music is a very profitable venture. In the case of "O bone Jesu," rehance

82. See generally Paul J. Heald, Payment Demands for Spurious Copyrights: Four Causes of Action, 1 J. INTELL. PROP. L. 259 (1994) (arguing that purchasers who mistakenly rely on a seller's false claim of copyright can recover under theories of common law fraud, unjust enrichment, consumer fraud, and breach of warranty).

83. KRASILOVSKY \& SHEMEL, supra note 9, at 262.

84. The distributor included two other short works by Brahms for the $\$ 1.60$. I will continue to use the $\$ 1.60$ figure because it was impossible to purchase "O bone Jesu" by itself. 
on the copyright claim by the music purchaser increases the buyer's cost more than fifty-fold.

A comparison of the original 1865 publication ${ }^{85}$ with the recently ordered version ${ }^{86}$ reveals the entirely spurious nature of the latter's copyright claim. The 1979 publication of "O bone Jesu" is exactly the same as the public domain version. All notes and dynarmic markings are identical. A more blatant abuse of the registration symbol, a symbol which carries with it the threat of significant civil and criminal penalties for copyright infringement, ${ }^{87}$ could scarcely be imagined. Music published abroad often presents this problem, given that copyright protection for new editions of music is more easily available there. ${ }^{88}$

Not all spurious claims are so blatant. Appendices B1 and B2 contain the original public domam version and a "copyrighted" 1954 version of William Billings' anthem "Jordan." quite identical. Although the notes are precisely the same in the two pieces, the 1954 version (Appendix B2) adds slurs ${ }^{90}$ whenever two notes are sung on the same syllable, and writes out the repeat of the refrain that Billings liad economically marked instead with a repeat sign. The 1954 publication also includes a piano reduction for rehearsal only (the piece is meant to be performed a capella) which is no more than the notes the choir sings convemently marked in one system. ${ }^{91}$ The reduction is not a new liarmoniza-

85. See Appendix A1. This reproduction come from an undated Carus-Verlag Stuttgart publication of Johannes Brahms, Geistliche Chormusik 128. The editorial notes in the introduction do not suggest that changes have been made from the original. See id. at 15-17. The sheet inusic itself is preceded by a facsimile of its original 1865 cover. Id. at 127. Note that the publisher of this public domain version is also the publisher of the "copyrighted" version in Appendix A2.

86. Reproduced as Appendix A2.

87. See 17 U.S.C. $\S 504$ (1994) (providing civil damages of up to $\$ 20,000$ per infringement); 18 U.S.C. $\$ 2319$ (1994) (allowing criminal penalties of up to ten years in prison).

88. For example, in some European countries, sheet music featuring a new typeface is protectable. See infra note 135 and accoinpanying text.

89. See 3 THE COMPLETE WORKS OF WIILIAM BILLINGS, supra note 8, at 180-81.

90. A slur is "a curved line extended over a smaller or larger succession of notes to imdicate the grouping of thein with a certain continuity." See 17 THE NEW GROVE DICTIONARY OF MUSIC AND MUSICIANS 385 (Stanley Sadie ed., 6th ed. 1980) [hereinafter NEW GROVE DICTIONARY]. Importantly, in choral music, "slurs are conventionally (and unnecessarily) notated only over notes all of which are to be sung on a single syllable." Id.

91. The reduction does move the tenor line up an octave, which is what most pianists playing without the reduction would do. Although a competent pianist could certain- 
tion or a different tune to be played contrapuntally against the choir, but inerely the same notes that the choir sings, written to inake playing thein on the piano easier while the choir sings those notes in rehearsal.

The copyright claim placed on the 1954 publication is almost certainly spurious. It flunks even the laxest originahty standard proposed in the cases discussed above..$^{92}$ Slurs are a convenience that add nothing original to the piece-it would sound the same without them. In the words of one authority, they are "unnecessary" in this sort of choral music. ${ }^{93}$ Writing out the repeat is merely realizing Billings' own scoring. And, as inentioned above, the piano reduction is just that - a mechanical condensation of Billings' own work with nothing new added. We have no new words or harnonies or other new material of any kind. The 1954 publication, although not identical to the public doinain work, is not "an original work of authorship" as required by the Constitution and the Copyright Act. $^{94}$

A good illustration of a valuable, but probably unoriginal, publication-the final chorus of Act III ("Hallelujah, Amen") of Handel's oratorio "Judas Maccabäus" _appears as Appendix C2. The 1933 publication allows a clioir to perform the final chorus without having to buy the entire 200 page oratorio. ${ }^{96}$ The orchestral accompaniment, which a church choir director niay not want, is also economically deleted. However, as noted in Part I above, ${ }^{97}$ the constitutionally and congressionally nrandated test for copyrightability is not usefulness or value, but rather originality.

What is original about the 1933 publication? The credited editor, Norwood Hinkle, marks a repeat of the first twenty-two ineasures that is not indicated in the original. ${ }^{98}$ In a couple of places where Handel ties two quarter notes, Hinkle writes them out as a half note, while inaintanimg the original ties. Handel's

ly play the piece on the piano without the reduction, writing it out makes playing easier.

92. See supra notes $61-81$ and accompanying text.

93. 17 NEW GROVE DICTIONARY, supra note 90 , at 385 .

94. See supra notes $27-40$ and accompanying text.

95. G.F. Handel, "Hallelujah, Amen" from Judas Maccabäus (1933 version) (Norwood Hinkle, ed.).

96. See, e.g., G.F. Handel, Judas Maccabäus (Arthur D. Walker ed.) (an undated, uncopyrighted publication containing a score of the entire oratio). Appendix $\mathrm{Cl}$ has been taken from this publication.

97. See supra notes $27-81$ and accompanying text.

98. Handel, supra note 95. Appendix C2 does not contain measures 21-38. 
work largely lacks dynamic markings. Hinkle marks " $m f$ " on measure 5 , " $f$ " on measure 12 , and " $f f$ " on measure $14 .{ }^{99} \mathrm{He}$ indicates the teinpo at "Allegro, a tempo giusto"100 whereas Handel had indicated several pages earlier in the original score "andante allegro."101 Most important, however, the melody, the harmony, and the rlyythm printed in the two pieces are identical. The Hinkle edition is essentially the same as the original piece that Handel first directed in 1747.

These three comparisons reflect imdustry practice as gleaned from forays through my church's music collection and the Umiversity of Georgia's Music Library. Some spuriously copyrighted publications appear to be no different from the original ("O bone Jesu"); soine show a few trivial differences ("Jordan"); and some reveal numerous trivial differences ("Hallelujah, Amen"). The effects of their copyright claims are identical, however-a great number of music purchasers choose to buy additional copies of sheet music instead of photocopying at less expense in deference to these works' spurious copyright syinbols.

\section{When IS AN ARRANGEMENT OF PUblic DOMAIN MUSIC PROTECTED?}

The problem created by spurious copyright claims is not imsoluble. If the consciousness of inusic purchasers, and of the attorneys and professors who may advise thein, is sufficiently raised (the objective of Parts I and II), and they are provided with a workable standard to judge the originality of the typical features of an arrangement of a public domain composition (the immediate objective), the costs of the current predicament can be significantly reduced.

A relatively limited number of musical techniques are used to add to, or delete from, a public domain work. The most common sorts of tinkering can be judged im light of copyright policy and the extant caselaw to define a fairly clear standard to govern whether an arrangement is original enougln to be copyrighted.

99. Id. Hinkle also marks "poco dim." on measure 23, "cresc." on measure 25 , " $f$ " on measure 29, and "ff adagio" on measure 35. Id.

100. "Lively, at an exact tempo." 1 NEW Grove DictionaRY, supra note 90, at 268; see also 7 NEW GROVE DICTIONARY, supra note 90, at 419.

101. See Handel, supra note 96 , at 211 . Andante allegro is defined "[a]t a lively walking pace." 1 NEW GROVE DICTIONARY, supra note 90, at 268, 397. 
Surprisingly, the Court's decision in a case not involving music, Feist Publications, Inc. v. Rural Telephone Service Co. ${ }^{102}$ is perhaps most helpful. In finding the telephone white pages to be unoriginal, the Court found their arrangement to be "inechanical," "routine," "practically inevitable," and an "age-old practice, firmly rooted in tradition." 103 The white pages were "entirely typical," "garden variety," and "obvious."104 The Court indicated that conventionality and lack of significant choice are the keys to judging the originality of derivative works, ${ }^{105}$ this notion is very helpful in judging the originality of arrangements of public domain music.

The only appellate case decided after Feist that discusses originality in the context of musical arrangements echoes this sentiinent. In Woods v. Bourne Co., the Second Circuit approved an imquiry that focused on whether the arranger exercised "dehiberate aesthetic choices" or whether he was merely "applying conventional rules of harmony." 106 Conventional "cocktail pianist variations" are not sufficient. In fact, the ease with which inconsequential or conventional additions to music may be made may have resulted in a stricter standard than absolutely required by Feist itself. ${ }^{107}$

One finds a similar focus on convention $\mathrm{m}$ non-music decisions after Feist. For exainple, in finding a title insurance commitment unoriginal and unprotected by copyright law, the Seventh Circuit found that the selection of data to be imcluded in the form "was not a matter of discretion based on Mid America's personal judginent or taste, but instead it was a matter of convention."108

102. 499 U.S. 340 (1991).

103. Id. at $362-363$.

104. Id. at 362 .

105. By definition, a phone book is a compilation, and not technically a derivative work, although the definitions plainly overlap. See 17 U.S.C. $\$ 101$ (1994). Both are treated together, however, for the purposes of scope of protection. See 17 U.S.C. $\S 103$ (1994) ("The copyright in a compilation or derivative work extends only to the material contributed by the author of such work, as distinguished from the preexisting material employed in the work, and does not imply any exclusive right in the preexisting material."). Recent opinions do not indicate that a different standard of originality should be applied to the author's contribution in the two cases. See, e.g., Tempo Music, Inc. v. Famous Music Corp., 838 F. Supp. 162, 168 (S.D.N.Y. 1993) (employing Feist to judge the originality of Duke Ellington harmonies to "Satin Doll").

106. Woods II, 60 F.3d 978, 992 (2d Cir. 1995). See supra notes 61-70 and accompanying text.

107. See 1 Melville NimMER, NIMMER ON COPYRIGHT § 2.05[C], 2-57 (2d ed. 1978) (noting a "tendency to require a somewhat greater degree of originality in order to accord copyright in a musical arrangement").

108. Mid America Title Co. v. Kirk, 59 F.3d 719, 722 (7th Cir.), cert. denied 116 S. 
The contribution of the putative copyright holder was "too rote and mechanical." 109

The Mid America opinion denies copyright protection for much the same reasons that a patent is invalid if it represents only an insignificant iniproveinent over a patent already issued-the improvement being "obvious" to someone experienced in the relevant art. ${ }^{110}$ Both the copyright law originality requirement and the patent law non-obviousness requireinent focus on whether the derivative work is the result of conventions familiar to creators working in the relevant culture. In noting this similarity, a lawyer friend with a D.M.A. im piano performance suggested to me that an accurate articulation of the originality test might be whether a derivation is "within the range of the musical culture."111 This formulation resonates with the patent law obviousness standard.

Regardless of the precise articulation of the test, the focus on conventionality is very helpful in evaluating the originality of the sort of activities that arrangers engage in.

\section{A. Orchestral and Choral Reductions}

A sufficiently original reduction of an orchestral work ${ }^{112}$ into a form playable on a keyboard is copyrightable. Although some decisions ${ }^{113}$ suggest a very stringent standard for musical reductions, in Wood v. Boosey, ${ }^{114}$ an English court found that a piano arrangement of an opera was original. The multiple lines of music played by various orchestral instruments in a complex operatic or symphorric work can be realized for piano in many different ways. In the absence of accepted musical conventions which would ren-

Ct. 520 (1995).

109. Id. See also Victor Lalli Enter., Inc. v. Big Red Apple, Inc., 936 F.2d 671, 673 (2d Cir. 1991) (stating that a document must "demonstrate the requisite mimimal originality" in order to receive copyright protection).

110. See 35 U.S.C. § 103 (1994).

111. Interview with David Wolfsohn, J.D., University of Chicago; D.M.A., Manhattan School of Music (Aug. 4, 1995).

112. See John Philip Sousa, The Stars \& Stripes Forever: For Two Pianos, Eight Hands (1988) (arranged by Mack Wilberg).

113. See Carte v. Duff, 25 F. 183 (S.D.N.Y. 1885) (fmding arrangement of Gilbert and Sullivan's "Mikado" unoriginal).

114. 3 L.R.-Q.B. 223 (1868). 
der reductions of an opera substantially the same, ${ }^{115}$ Wood $v$. Boosey would seem to be correctly decided.

Of course, a derivative reduction composed "in the spirit of" the original work which diverged significantly froin the original in melody and harmony would also be copyrightable. Under Feist, the key to judging the originality of a reduction would seen to be the number of significantly different options that could be exercised by the arranger. One of the reasons why the telephone book in Feist was uncopyrightable was the lack of choices available to someone arranging phone numbers in a book-alphabetical order is the choice dictated by convention. ${ }^{116} \mathrm{~A}$ similar lack of choice in choosing and arranging the yellow pages subject headings drives the holding of unoriginality in Bellsouth Advertising \& Publishing Corp. v. Donnelley Information Publishing, Inc. ${ }^{117}$ Under Feist, a mechanical reduction of an orchestral score that is dictated by musical convention, where the arranger exercises no significant choices, would not be original. Choices made outside the dictates of convention would be protected.

Most piano reductions of non-orchestral works, such as choral arrangements, are entirely dictated by the choral parts. Billings' "Jordan" in Appendix B2 provides a good example of this. ${ }^{118}$ Since the reduction is dictated by the vocal parts, it is unprotected. As already noted, most piano reductions of choral works are merely the sung notes reproduced for the pianist's convemience onto a system below the choral lines. ${ }^{119}$ No new musical material is added. On the other hand, an accompaniment that added original harmonizations or a new contrapuntal melody would be protected. The presence of a sufficiently original piano or organ part does not, however, absolutely prevent the use of the arrangement. Blocking out the protected material before photocopying is permissible. ${ }^{120}$ In addition, new music software makes it quite easy to

115. See discussion of the realization of figured basses infra notes 132-34 and accompanying text.

116. See Feist Publications, Inc. v. Rural Tel. Serv. Co., 499 U.S. 340, 363 (1991) ("It is an age-old practice, firmly rooted in tradition and so commonplace that it has come to be expected as a matter of course.") (citing Brief for Information Industry Assoc. at 10 (no. 89-1909)).

117. 999 F.2d 1436 (11th Cir. 1993) (holding that the selection and arrangement of the Miami Yellow Pages is not original).

118. See supra text accompanying note 91 .

119. See id.

120. See 17 U.S.C. $\& 103$ (b) (1994) (copyright to derivative works does not extend to 
print out only the public domain parts of a musical composition in an alternative and convenient forinat. ${ }^{121}$

\section{B. New Harmonies}

Although some older caselaw suggests that harmonic additions to public domain music are unprotectable as a matter of law, ${ }^{122}$ the opinions are ultimately unconvincing. The facts of Cooper $v$. James $^{123}$ illustrate the problent. Many songs in the first pubhished versions of the famous "Sacred Harp" hymnal were written in three-part harmony; they lacked an alto line. In other words, all women would sing the soprano line or the tenor line pitched up an octave. The copyright claimant in Cooper wrote alto lines for compositions in the lymnal and sued when they were copied by a competitor. The court held that the addition of an alto harmony could never be sufficiently original. ${ }^{124}$ When viewed from a latetwentieth-century perspective, this holding seenis hopelessly outdated both jurisprudentially and inusically.

The court in Cooper apphes the "mere nrechanic" test of Jollie v. Jaques ${ }^{125}$ and reasons that originality is lacking because any musician of reasonable talent could compose an alto part. This may be true, but after Feist the question is not the talent level of the coinposer, but whether significant choices were exercised in the course of the harmonization. In other words, were these nuusicians

pre-existing materials).

121. Intermediate copying of protected musical material in order to access and reproduce only the public domain elements should constitute a fair use of the protected material. See 17 U.S.C. § 107 (1994) (defining "fair use" of copyright). For example, a new English translation of the words of a public domain Latin hymn is probably protected by copyright. A choir director may wish to perform the unprotected ancient Latin version. Copying the entire composition, including the new translation, in order to block out the new English words, leaving only the public domain music and Latin lyrics for distribution to the choir is almost certainly a fair use. See Sega Enter. Ltd. v. Accolade, Inc., 977 F.2d 1510, 1520 (9th Cir. 1992) (holding that copying protected elements of computer prograin in order to gain an understanding of unprotected functional elements is fair use); Atari Games Corp. v. Nintendo of America, Inc., 975 F.2d 832, 839 (Fed. Cir. 1992) (holding that downloading copyrighted material to access its public domain components can be permissible fair nse).

122. See Northern Music Corp. v. King Record Distrib. Co., 105 F. Supp. 393, 400 (S.D.N.Y. 1952); Cooper v. James, 213 F. 871,872 (N.D. Ga. 1914).

123. 213 F. 871 (N.D. Ga. 1914).

124. See id. at 872-73.

125. 13 F. Cas. 910 (C.C.N.Y. 1850) (No. 7,437) (holding arrangement of "The Serious Family Polka" uncopyrightable). 
of "reasonable talent" guided in writing similar alto lines by existing musical conventions? A line dictated by accepted rules of composition would not be original, but if the rules permitted nuinerous harmonic possibilities or if the new alto part broke significantly froin convention, then it would be original. A musicologist familiar with the harmonic conventions of the era and a sense of the options available to a composer of an alto line written in the style of Southern Harmony could tell us whether the alto parts at issue in Cooper were original or not. ${ }^{126}$

The more recent decision in Tempo Music Inc. v. Famous Music Corp. ${ }^{127}$ would seem more in tune with both the principles of Feist and modern music theory. At issue were harmonies coinposed by jazz great Duke Ellington. The court rejected the defendant's claim that harmony "results only from the formulaic apphication of centuries-old compositional rules."128 Recognizing the breakdown of conventions in modern Western music, the court noted that "in the jazz music genre, musicians frequently move beyond traditional rules to create a range of dissonant and innovative sounds." 129 Emphasizing the choices available to (and made by) Ellington in his harmonization of "Satin Doll," the court found the harmonies to be sufficiently original. While recognizing that "m inost instances, harmony is driven by melody," those cases be unprotected, the court refused to "deprive appropriate protection to composition which contains sufficient originality and creativity to warrant such protection."131

The inquiry into the originality of a harmony is similar to the inquiry into the originality of a reduction. What choices were available to the coniposer? Has the liarmony been dictated by preexisting elements in the public domain work or is it a break from

126. "Southern Harmony" is a style best characterized by the music contained in William Walker's Southern Harmony and Musical Companion. See WILlIAM WALKER, SOUTHERN HARMONY AND MUSICAL COMPANION (Glenn C. Wilcox ed., 1987) (containing a collection of hymns, tunes, odes, psalms, and anthems first printed in 1854). The melody in Southern Harmony is generally found in the tenor line and, in order to facilitate singing by untrained voices, the music is often written in "shape notes" rather than traditional notation. See id. at v-viii. Most songs in Southern Harmony lack an alto line entirely. See id. at $\mathrm{x}$.

127. 838 F. Supp. 162 (S.D.N.Y. 1993).

128. Id, at 168 .

129. Id.

130. Id. at 169 .

131. Id. 
musical convention? Obviously, the originality of a harmony must be judged on an ad hoc basis and with the help of a musicologist who understands the nature of the real choices, if any, exercised by its composer.

\section{Realizing Figured Basses, Rekeying, and Recleffing}

Johann Sebastian Bach, like many of his contemporaries, did not write out in modern musical notation the harmony to his compositions, but instead indicated those lines numerically. ${ }^{132}$ This convenient device enabled a Baroque composer to save the time and space it would have taken to write out the composition completely. Although a talented keyboard player can play directly from the figuring, ${ }^{133}$ inost inodern arrangers of works containing figured basses write thein out in standard notation. A realization of a figured bass line is almost certainly not protected because the realization evinces very hittle, if any, choice on the part of the arranger. Competent arrangers realizing a figured bass will inevitably write it out in inuch the same way, thereby failing to meet Feist's originality requirenient.

Similarly, an arrangement is unprotected if it merely transposes the entirety of a public donrain work into a new key to make it easier (or in the case of a bad or weird arrangement, harder) to sing or play. Transposition from key to key is entirely mechanical and free of choice. Any coinpetent musician (or a computer program) will produce the same piece when asked to transpose "Jordan" from A nnajor to C major. The same rationale that results in the protectability of the realization of a figured bass and many piano reductions dictates that the mere rekeying of a piece is unprotected.

The conversion of an older piece of music notated in an obsolete clef $^{134}$ into modern bass or treble clef is also an unprotectable contribution. The recleffed work will sound exactly the sanie and the process of recleffing is entirely mechamical. No choice is exercised by the person (or computer) doing the work.

132. See 6 NEW GROVE DICTIONARY, supra note 90, at 544-45.

133. See Smith, supra note 17 , at 112 n.45.

134. A clef is "[t] $\mathrm{the}$ sign placed at the beginning of a staff to denote the pitch of one of its lines." See 4 NEW GROVE DicTIONARY, supra note 90, at 473-75 (discussing the history of the uses of various different clefs). Only bass and treble clef are considered standard for modern choral coinpositions. 
The sole motivation of the arranger is the convenience of the performer who may not feel comfortable with an unfamiliar clef.

\section{Typeface and Facsimile Editions}

American law, unlike that of some foreign countries, ${ }^{135}$ does not extend copyright protection to typefaces. ${ }^{136}$ Therefore, a music publisher cannot obtain protection for a new publication of a public domain work simply by reprinting it in a different type. For similar reasons, a facsimile edition of a composer's original works (perhaps even of the imitial handwritten drafts ${ }^{137}$ ) is unprotectable. Although West Publishing has argued that its formatting of opimions and page placement is protected by copyright law, ${ }^{138}$ this assertion probably does not survive Feist. ${ }^{139}$

\section{E. Critical Comments and Corrections}

Significant editorial comments that accompany a public domain composition may be protected. A recent edition of the complete works of William Billings contains significant introductory, historical, and critical materials that are protected original expression, even though most of the compositions themselves can be freely copied. ${ }^{140}$ Sometimes such comments appear on the musical composition itself. As noted above, one can always avoiding infringing such material by blocking it out before photocopying. ${ }^{141}$ Copying the commentary itself may even be a fair use, if it is only copied to access the public domam material and is not itself exploited by the copier. ${ }^{142}$

135. See, e.g., J.H. Reichman, Design Protection in Domestic and Foreign Copyright Law: From the Berne Revision of 1948 to the Copyright Act of 1976, 1983 DukE L.J. 1143, 1243 n.525 ("Typeface designs are protectible as ornamental designs under the Italian Design Law of 1940." (citation omitted)).

136. See Monotype Corp. v. International Typeface Corp., 43 F.3d 443, 446 (9th Cir. 1994).

137. An example of this would be Handel's Messiah, on file in the University of Georgia music library. See Handel's Conducting Score of Messiah (reproduced in facsimile from the Manuscript in the Library of St. Michael's College, Tenbury Wells) (1974).

138. See West Publ'g Co. v. Mead Data Cent., Inc., 799 F.2d 1219 (8th Cir. 1986).

139. See Heald, supra note 31, at 160-61 (arguing the likelihood that Feist overrules West, noting that the Feist opinion cites to a law review critical of West).

140. See THE COMPlete Works of William BILIINGS, supra note 8, at xiii-lxiii.

141. See supra note 120 and accompanying text.

142. See supra note 121 and accompanying text. 
Many editorial choices, however, may be too trivial to be protected at all. For example, the original version of "Jordan,"143 taken from a wonderful edition of his complete works edited by Karl Kroeger, ${ }^{144}$ is not exactly what Billings wrote. The collection, on occasion, makes corrections when Kroeger thinks that the initial publication was misprinted in some way. In "Jordan," for example, he places the notation "Forte" over measure 25, where it sensibly belongs. ${ }^{145}$ This move puts it over "So" which clearly starts a new musical thought, rather than over "to," which would be an awkward and unconventional place to begin an increase in volume. The notes to the Kroeger edition indicate that the first publication of "Jordan" placed the "Forte" erroneously over measure $26^{146}$ We can be grateful to Kroeger, and to subsequent publishers who lave moved Billings' "Forte" to the place where he probably intended it, but this contribution is unoriginal in the constitutional and statutory sense.

One commentator who argues for the increased protection of editorial changes reasons that the law should "reward[] those editors who, through diligent effort and research, have preserved the integrity of the original." 147 His rationale for protection reveals why most editorial changes cannot be constitutionally protected. First, according to the court in Feist, "copyright rewards originahity, not effort." 148 The court expressly rejected the "sweat of the brow" rationale that was once generally accepted. ${ }^{149}$ Second, editorial clianges that are designed to make a composition truer to the composer's intent would seem by definition to be unoriginal. Such efforts are by definition intended not to create a new work, but to preserve the essence of the old. Although one could iniagine that a very speculative edition of an ancient inusical fragment incorporating numerous creative choices might be protectable, the run-of-the-mill changes made to most commonly performed compositions are, for better or worse, usually unoriginal in the legal sense.

143. See Appendix B1.

144. See 3 THE COMPLETE WORKS OF WILLIAM BILIINGS, supra note 8, at 180-81.

145. This is the only change he makes. See id.

146. See id. at 376.

147. See Smith, supra note 17 , at 137.

148. Feist Publications, Inc. v. Rural Tel. Serv. Co., 499 U.S. 340, 364 (1991).

149. Id. at 352 . 


\section{F. Fingering}

Some publications of public domain compositions include helpful notations indicating how the piece slould be physically realized on a particular instrument. Compositions for string instruments in particular occasionally include fingering, bowing or articulation notations. These suggestions on how to play a series of notes are sometimes imcluded for beginners learning how most easily to play a piece, or they may be suggestions for accomplished musicians experimenting with various ways of interpreting the piece. ${ }^{150}$ On some instruments, the choice of fingering or bowing methods can directly affect the sound made by the instrument and therefore the performer's interpretation of the piece. ${ }^{151}$

Notation that is designed to make a piece easier for the novice to play should be unprotected. Accepted methods of fingering or bowing that are dictated by ease of playing are not original. Significant interpretative choices made by performers of string music, however, can depend on various fingering or bowing options. ${ }^{152}$ The mere existence of options, however, is not dispositive. Although a musician may make one imterpretive choice among several, the originahity standard may still not be met within the relevant musical genre or culture.

An example may serve to illustrate the problem. Imagine a modern arrangeinent of the Bach Sonata in C Major for two violins and harpsichord ${ }^{153}$ which indicates that the strings should be fingered by a violinist wearing aluminum thimbles. Sucl an original and unconventional notation would arguably be protected. Imagine, on the other liand, the three alternative fingerings suggested by Ronald Smith for the first movement, measures 3-4, of the second violin part of the same Bach sonata. ${ }^{154} \mathrm{He}$ explains

150. See Smith, supra note 17, at 136-37 n.203 (discussing four possible fingerings of Bach's Sonata in C Major for two violins and harpsichord). See generally 6 NEW GROVE D1CTIONARY, supra note 90, at 567 (defining "fingering").

151. See Smith, supra note 17 , at 136 ("A difference in fingering ... is often the difference between a mediocre performance and one of artistry. This is equally true of bowing . . ...").

152. See id. at 136 n.203.

153. BWV 1037 (1741). It is interesting to note that authorship of this sonata las, in fact, been attributed to Johann Gottlieb Goldberg. See THEMATISH-SYSTEMATISCHES VERZEICANIS DER MUSIKALISCHEN WERKE VON JOHANN SEBASTIAN BACH 754 (Wolfgang Schmeider ed., 1990).

154. See Smith, supra note 17, at 136-37 n.203. 
with great insight the differences in sound produced by the fingerings that he offers, the aesthetic advantages of each, and the skill required to play each option. His discussion concludes that "[b]ecause of the originality and intellectual labor required in designing them, fingerings are worthy of copyright protection." Without the teaching of Feist and Woods v. Bourne Co. at his disposal, he is not prompted to offer an opinion on how conventional his suggested fingerings are. Are these variations that any "cocktail violinist"156 would naturally offer? Are they obvious options well within the range of the inusical culture? If they answer to these questions is "yes," then it's difficult to see how any of the fingerings offered by Smith would be protected under current precedent.

\section{G. Rhythm: Meter, Ties, and Bar Lines}

Although an early case suggests that rhythm is not protectable, ${ }^{157}$ one can imagine how extensive rhythmic changes might inake a public domain work virtually unrecognizable. While an original rhythmic contribution to a public doinain work is conceivable (for exainple, imagine a rap version of the fourth movement of Beethoven's Ninth Symphony), many arrangers tinker with rhythmic notation merely to make perfornance of the piece easier. For instance, altliough the director of our church choir remetered several measures of a piece we recently sang, her inotivation was not to create an original work of authorship but to facilitate her choir's reading of the piece. She felt that the shifting meter of the original which enabled the maintenance of even note values was distracting, and rewrote it in a single meter with shifting note values to make the piece easier to sing.

My director's practice-one that is not uncommon-raises two issues. First, one must judge the originality of lier choice to change the metering by comparing it to musical conventions governing the transposition of meter. ${ }^{158}$ Second, one must ask the question whether a change in the written expression of music which does not cliange the sound of the piece when performed could ever be

155. Id.

156. See supra text accompanying note 14 .

157. See Northern Music Corp. v. King Record Distrib. Co., 105 F. Supp. 393, 400 (S.D.N.Y. 1952).

158. In other words, would another director testify, "That's an obvious thing to do"? 
the subject of copyright. At least some opinions suggest that the originality of new version of an existing musical work turns on whether it sounds sufficiently different than the existing one. ${ }^{159}$ Under this test, my director's changes are surely unoriginal-they effect no difference at all. Since the reason for reducing music to tangible written expression is to stimulate a particular sound when it is performed, this focus on the lack of aural difference may be consistent with the rationale of the originality requirement. My director's changes had the same effect as the work of the skilled artisan who carefully cleans the mold and grime off of the fresco of the Last Supper. They both make the underlying work of art more accessible, but their contribution is not original in the copyriglit sense. ${ }^{160}$

Raising a similar issue are many works written centuries ago, such as Gregorian chants, that contain no bar lines or indication of meter at all. One must remember that just because a piece lacks rhythmic markings does not mean that an exact rhythm is not generally understood to be iniplied. Markings may be lacking, not because the composer did not care how a piece was sung, but rather because he knew that given existing conventions, no real performance options existed. The musical culture's equivalent of the Uniform Commercial Code notion of "usage in the trade" fills many "gaps" that we may perceive in an old piece of music. An arranger who does nothing more than realize in modern notation what was, and may still be, understood as the conventional way to perform the piece has not made an original contribution.

An arranger, however, may go further and change the intended feel of a piece by shifting the overall meter and rebarring it, for example, taking a waltz and playing it as a two-step in cut time, without changing melody or harmony. ${ }^{161}$ Would such a rhythmically different arrangement of a public domain work be protected by copyright law? Protecting a cut time version of a public domain waltz would serve little or no purpose. It would reward the labor and industriousness of the arranger for making

159. See Tempo Music, Inc. v. Famous Music Corp., 838 F. Supp. 162, 168-69 (S.D.N.Y. 1993).

160. My director shares this conclusion.

161. See Joe Young, John Siras, \& Jack Little, In a Shanty in Old Shanty Town (M. Witmark \& Sons 1932). This publication contains both waltz and fox trot versions of the same melody. 
the mechanical adjustments to the original work, but would not really reward an original musical contribution. The arranger may have been the first to conceive of arranging the work in cut time, but copyright law does not offer protection to ideas. ${ }^{162}$ The tangible expression of an idea, which may be protected, is in this case a mechanical operation that involves no significant choice to be exercised by the arranger.

Obviously, some rhythmic changes are significant and could be protected. Walter Murphy published disco versions of several public domanı works on his 1972 "A Fifth of Beethoven" album. Such unconventional rhythmic gerrymandering may well be original; the fact that inuch tinkering with rlythm is insignificant does not mean that an arranger cannot, in fact, make an original contribution by making rhythmic changes.

\section{H. Dynamic Markings and Editing}

New arrangements of public doinain compositions frequently alter musical dynamics by adding or deleting slur marks and repeats, indications of crescendo and diminuendo, or volume markings. Such changes effect the inood, flow, or "feel" of the piece. Many public domain works contain sparse dynanric markings or lack them altogether. ${ }^{163}$ An arranger of such a work may add dynamics to realize the sound she beheves the composer originally intended for the work. As noted above, many older works lacked rhythmic or dynamic markings altogether because generally accepted inusical conventions dictated how the piece would be performed. ${ }^{164}$ Alternatively, the arranger may be trying to adapt a public doinani work to her own vision. For example, a section to be sung "marcato"165 may be changed to "legato"166 or a section may be changed to be sung "piano" instead of "forte." In fact, choir directors spontaneously inake these sorts of changes to a piece during rehearsal in an attempt to produce precisely the desired inusical effect.

162. See 17 U.S.C. \& 102(b) (1994).

163. See Appendices $\mathrm{B} 1$ and $\mathrm{C}$.

164. See supra text accompanying notes 160-61.

165. Translated, "accented" or "stressed". 11 NEW GROVE DictionaRY, supra note 90 , at 647.

166. Translated, "connected smoothly." 10 NEW GROVE DICTIONARY, supra note 90, at 610 . 
The originality of changes in dynamic markings turns on the overall effect they have on the sound of piece. As the Second Circuit stated in Woods v. Bourne Co., the arrangement must be "to some extent a new work with the old song embedded in it but from which the new has developed."167 Even though they may not affect the melody, harmony, or rhythm of a inusical composition, a significant audible difference may be perceptible since inarkings are directions to performers telling thein: "This is how you should sing this composition." The critical inquiry is whether the changes in dynamics are obvious-that is, suggested by relevant conventions-or not.

The issue of extensive, but obvious, textual editing arose in Grove Press, Inc. v. Collectors Publishers, Inc. ${ }^{168}$ In that case, the editor of a public domain biography made over 40,000 changes to grammar, syntax, and word choice. This extensive editing was found not to be protected by copyright law. The court found that mere editing of the sort any "high school Enghish student" could do was not sufficiently original. ${ }^{169}$ The new edition undoubtedly had a different "feel" than the public domain book, but the court required more of an original contribution to its essence. No one demed the value of the editorial contributions to the new publication, but the test under Feist, again, is not value or usefulness but originality measured as departure from convention. ${ }^{170}$

Viewed in light of the copyright bargain discussed above, denying protection to insubstantial changes in dynamics makes sense. Massaging an existing work is not the same as creating an original derivative work. If one could obtain copyright protection merely by adding a "forte" to a measure of a public doinain composition, a dangerous "weapon for harassment" would be available for anyone to exploit. ${ }^{171}$ The originality standard would be no standard at all if a trivial variation would suffice for copyright. Would extensive and radical changes in dynamic markings be original? Substantial additions that worked a significant change to the essence of the piece could suffice. Additions that are "typical,"

167. Woods II, 60 F.3d 978, 991 (2d Cir. 1995) (citation omitted).

168. 264 F. Supp. 603 (C.D. Cal. 1967).

169. Id. at 605 .

170. See Feist Publications, Inc. v. Rural Tel. Serv. Co., 499 U.S. 340, 362-64 (1991).

171. L. Batlin \& Son, Inc. v. Snyder, 536 F.2d 486, 492 (2d Cir. 1976) (en banc). 
"routine," "obvious," or "practically inevitable," to use the Feist phraseology, should be insufficient.

\section{ADMINISTRATIVE OR STATUTORY SOLUTIONS}

As the preceding discussion suggests, users of public domain music trying to determine whether a registered work is in fact original find little concrete guidance im legislation or in the existing caselaw. In this respect, future courts will hopefully be able to provide some assistance with the help of expert witnesses. A court sensitive to copyright pohicy should be capable of determining which sorts of arrangements of public domain music are original. Furthermore, the decision in Feist should be enough to establish the importance of the originality requirement. Nevertheless, although the judiciary and secondary sources can help by clarifying the legal parameters of the originahity requirement, only Congress or the Copyright Office can help provide the relevant facts needed by those making decisions about whether to photocopy or to buy arrangements of public domain music: what changes did the arranger actually make to the public domain piece? No informed decision as to the originality of the arrangement can be made unless the additions and deletions made to the public domain work have been ascertamed. In spite of the fact that I hive in a city with a decent music library, I have had trouble collecting the public domam versions of various well-known works. Imagine the phight of the choir director or school administrator who has neither a major university music library in town nor the time to do significant sleuthing.

In rare instances, a consumer can obtain the relevant information from the Copyright Office. The Copyright Office requires the applicant for a copyright in a derivative work, like a musical arrangement, to disclose both the preexisting material on which the arrangement is based and also to make "a brief, general statement of the additional new material covered by the copyright claim for which registration is sought." 172 For a moderate fee, the Copyright Office will conduct a search and supply the application record. ${ }^{173}$ The information provided, however, will only be useful

172. See U.S. Copyright Office, Filling Out Application Form PA, at SPACE 6: Derivative Work or Compilation.

173. See KRASILOVSKY \& SHEMEL, supra note 9, at 263-64 (explaining Copyright Office inquiries). 
if the applicant was both honest and detailed in his or her application. Unfortunately, the directions on the application allow the arranger to respond very generally ${ }^{174}$ More importantly, in many cases the requested information cannot be obtained in a timely fashion, or is too costly.

In economic terms, we have a proble1n with prohibitively higlt search costs. A music buyer is unlikely to spend significant time in the library or contact the Copyright Office in order to ascertain whether a particular arrangement is original unless a significant amount of inoney is at stake. As noted above, ${ }^{175}$ althougli a liuge sum is at stake in the aggregate, each individual purchasing decision does not generally implicate sufficient savings in photocopying to justify incurring substantial searcl costs.

Several possible solutions suggest themselves. First, the Copyriglit Office, taking its cue from Patent Office practice, should require that "prior art" (the pre-existing composition) be submitted along with the derivative work sought to be registered. This would greatly facilitate the identification of precisely what an arranger has added to, or deleted from, an existing work. It would also clarify the nature of the claims made under the registration, because as a matter of law, material contained both in the pre-existing work and in the derivative work would not be protected. In addition, a coinposer should have to list all the eleinents of the new arrangement that she feels are original. ${ }^{176}$ An application for a derivative musical work would thus be like a patent application, where the inventor must specify precisely what claims lie is nnaking.

The Copyright Office or Congress could also einploy the Internet to drastically reduce consumer search costs and improve the quality of administrative decision making. The Copyright Office could, for example, establish a web site accessible on the Internet that would contam the information provided by applicants for copyrights in derivative musical arrangements. Consumers of public domain arrangements would then liave instant computer

174. For example, "Arrangement for piano and orchestra" will suffice. See Filling Out Application Form PA, supra note 172, at SPACE 6: Derivative Work or Compilation.

175. See supra notes $21-23$ and accompanying text.

176. The Copyright Office could, for example, require greater detail in answers given to Question 6(b) in Form PA. See id. Additional information on the application instructions would help arrangers understand what is an original contribution. 
access to the elements claimed as original in the arrangement. They could then make an informed choice whether to buy or to photocopy. Such a web site would likely be inexpensive to estabhish and maintain given current volume. The Office might even list information from past applications already on file. These administrative suggestions could eventually reduce the millions of dollars needlessly spent by public institutions, clrurches, and otlier consumers on unoriginal arrangements of public domain music.

Consumers of slieet music may also be able to force reform through hitigation. I have previously outlined four causes of action that could successfully be brought against those who make spurious claims of copyriglit to public donnain music. ${ }^{177}$ Consumer class actions based on breach of warranty, unjust enrichment, fraud, and consumer protection or false advertising statutes offer a promising means of dissuading those who profit from false claims. The imphication of a private cause of action in the criminal prohibition of falsely affixing a copyright symbol is also a possibility. ${ }^{178}$ This statutory provision may provide yet another avenue of deterrence. Of course, private hitigation would be unnecessary if the Department of Justice played a more active role in policing violations. A number of visible and substantial fines miglit provide the greatest disincentive of all against the plundering of the public domain. Slreet music without a copyright registration is hard to find now, but an aggressive hitigation strategy may make the absence of the symbol on public domain works more common.

\section{CONCLUSION}

Althougli the Constitution, the Copyright Act, and judicial opimion clearly require arrangements of public domain music compositions to be "original" to receive protection from copying, music publishers' persistent claims to public domain works have created a chmate where most consumers instinctively pay for new sheet music rather than copy it. High searcli costs and a dearth of appellate precedent make it difficult even for sophisticated consumers to imvestigate and clrallenge music publishers' spurious and very profitable claims to copyright. This Article has demonstrated, however,

177. See generally Heald, supra note 82 .

178. See 17 U.S.C. § 506(c). But see Donald Frederick Evans \& Assoc., Inc. v. Continental Homes, Inc., 785 F.2d 897, 912 (11th Cir. 1986) (no private right of action under 17 U.S.C. $\$ 506(\mathrm{c}))$. 
that caselaw, informed by copyright pohicy as explicated in Feist, can provide sufficient guidance-inost changes that arrangers make to public domain compositions can be adequately judged by the musically-informed layperson to be original or not. The most persistent problem lies in the determination of exactly what changes have been made. Only the Copyright Office or Congress can provide sufficiently clieap access to this information.

When publishing companies attempt to extend the protective reach of copyright laws to their advantage, they rely on the moving metaphor of the Aspiring Artist. ${ }^{179}$ Even though the Supreme Court explains that copyright law makes "reward to the owner a secondary consideration," $" 180$ it also recognizes that public welfare is advanced through the "talents of authors."181 The Court sees the entire picture: the interests of both the public and the author are at stake in the debate over the paranieters of copyright. The metaphor of the Aspiring Artist, then, only captures half of the story.

Other stories need to be told. The public domain will not continue to be robust if it remains a conceptual abstraction-direct and indirect consumers of music have little voice when the public domain is balanced against the more tangible interests of the Aspiring Artist. For this reason, the public domain needs its own avatar in the public debate. As this Article has demonstrated, the Choir Director and Musical Arranger are viable candidates. The Movie Director, borrowing liberally from public domain scènes $\grave{a}$ faire, plot twists, and stock characters, may be another. The Digital Future Coalition, a loose association of computer programmers and others with information age interests, nominates the Internet Surfer. ${ }^{182}$

179. See, for example, the World Wide Web edition of Playback, the bimonthly magazine of the American Society of Composers, Authors and Publishers (ASCAP). In the "Legislative Update" section of this year's January-February issue, ASCAP encourages readers to lobby members of Congress in favor of the proposed "Life Plus 70" copyright extension: "Those of us who make our living from our music, and those who hope to, deserve to be compensated when our music is used." PLAYBACK (1996) <http: //www.ascap.com/playback/1996/february/legislative.html\#congress> (emphasis added).

180. United States v. Paramount Pictures, Inc., 334 U.S. 131, 158 (1948).

181. Mazer v. Stein, 347 U.S. 201, 219 (1954).

182. In championing an amendment to proposed legislation affecting copyright on the Internet, for example, the Digital Future Coalition makes the following argument against labeling the unlicensed viewing of a web site as a copyright violation: "If such automatically erased images are considered true 'copies' under the Copyright Act, . . . the right 
Convincing economic argument in favor of protecting the public domain is one tool of persuasion. The inusic publishing industry, lowever, is best confronted by another-specific examples of the way $\mathrm{m}$ which the public domain benefits individuals. The experience of the Cloir Director is a good place to start.

and opportunity to browse information on-line now enjoyed by millions will be seriously underminded or-at some point soon-completely precluded." Digital Future Coalition, Digital Future Coalition Amendment to "NII Copyright Protection Act" Facilitating Browsing and Networking (visited Nov. 11, 1996) <littp:/www.ari.net/dfe/legislat/pagers.htm\#i106>. 


\section{APPENDICES}




\section{APPENDIX A1: "O BONE JESU" (PUBLIC DOMAIN VERSION)}

\section{$O$ bone Jesu}

Karfreitagsgesang

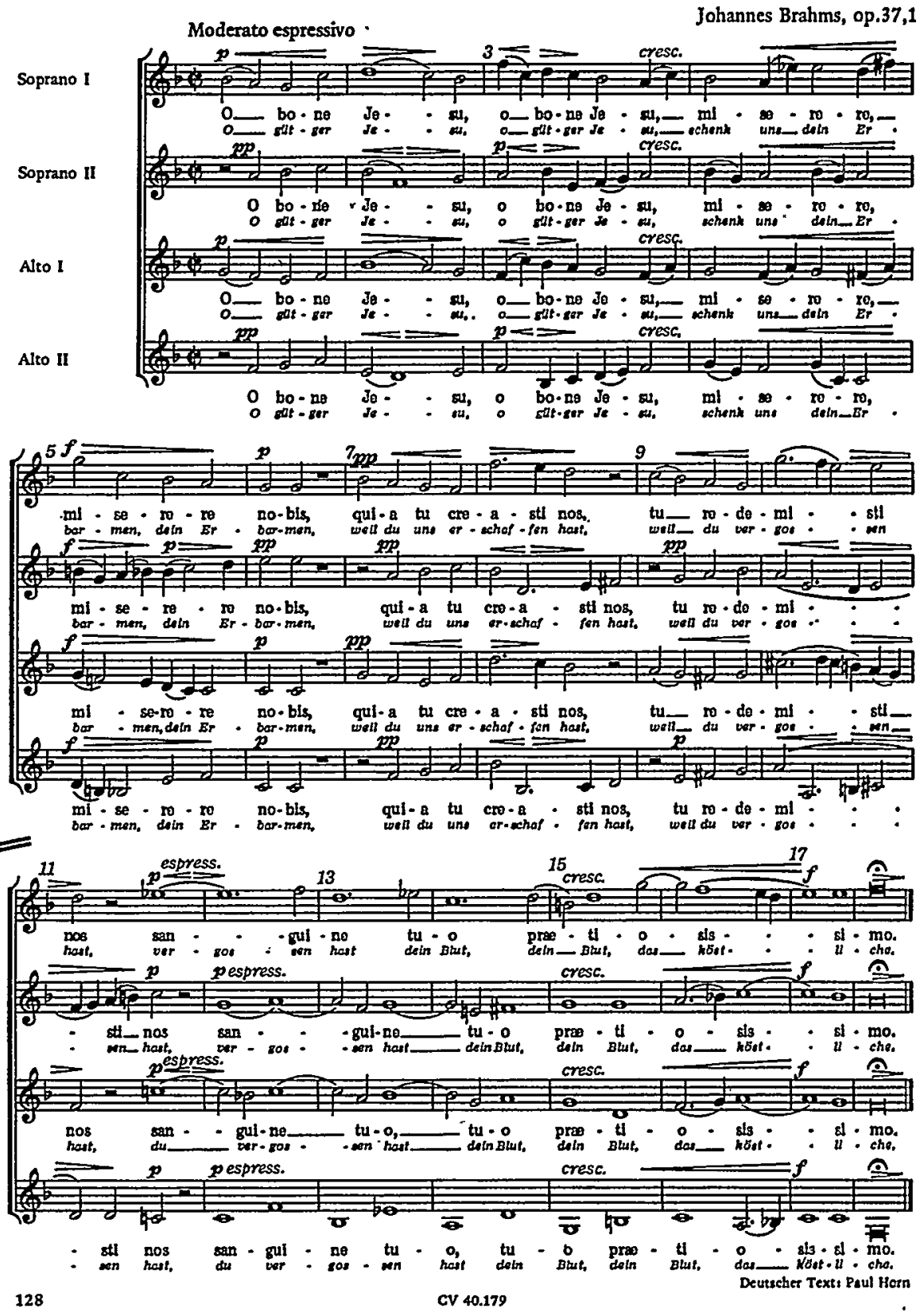




\section{APPENDIX A2: "O BONE JESU" ("COPYRIGHTED" VERSION)}

Drei geistliche Chöre für Frauenstimmen, opus 37

\section{O bone Jesu}

Johannes Brahms

Moderato espressivo

Sopranol
$\left(f^{\left.1-g^{2}\right)}\right.$

Soprano II

$\left(d i-e^{2}\right)$

Also 1
$\left(c^{2}-d 2\right)$

$\underset{\left(f-b^{1}\right)}{A l s o l I}$

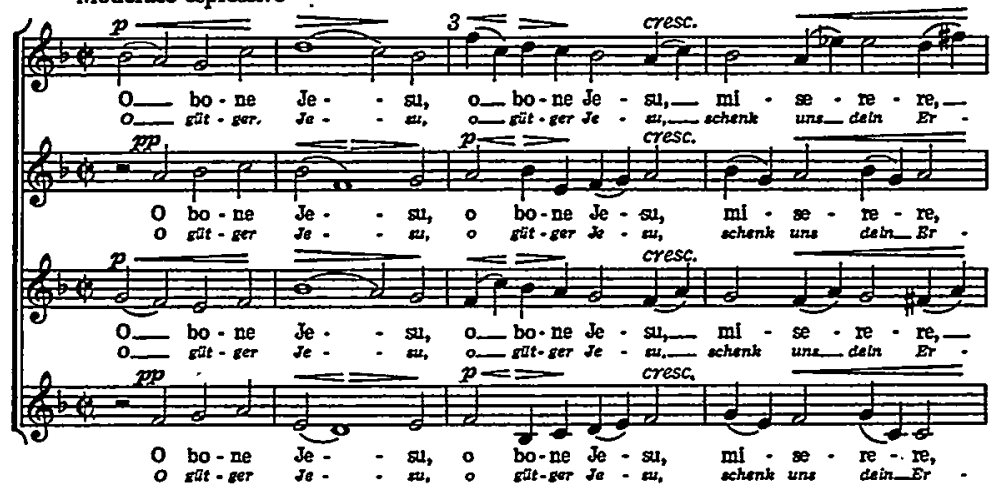

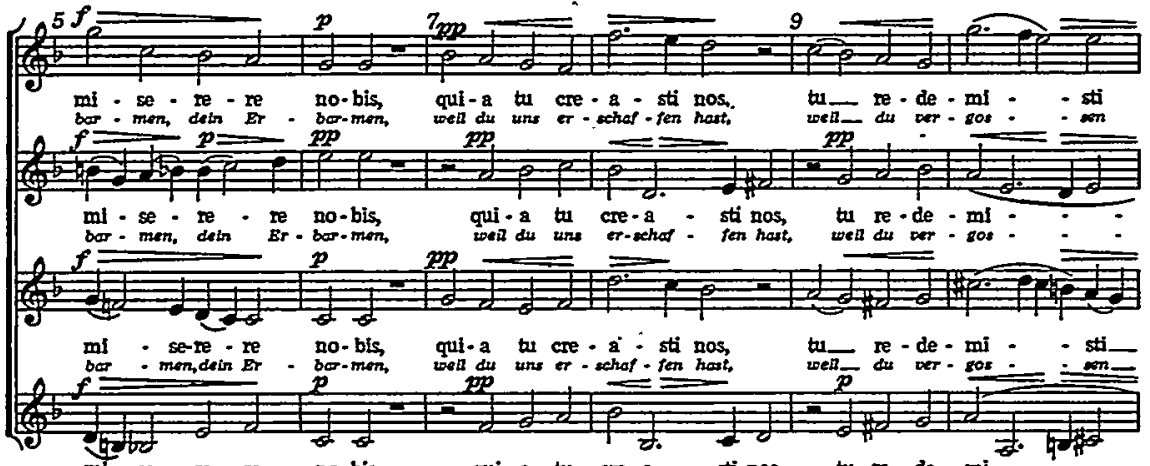

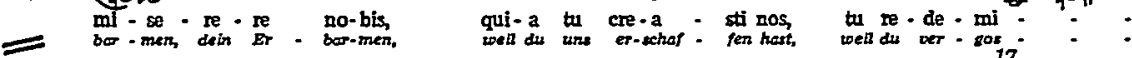

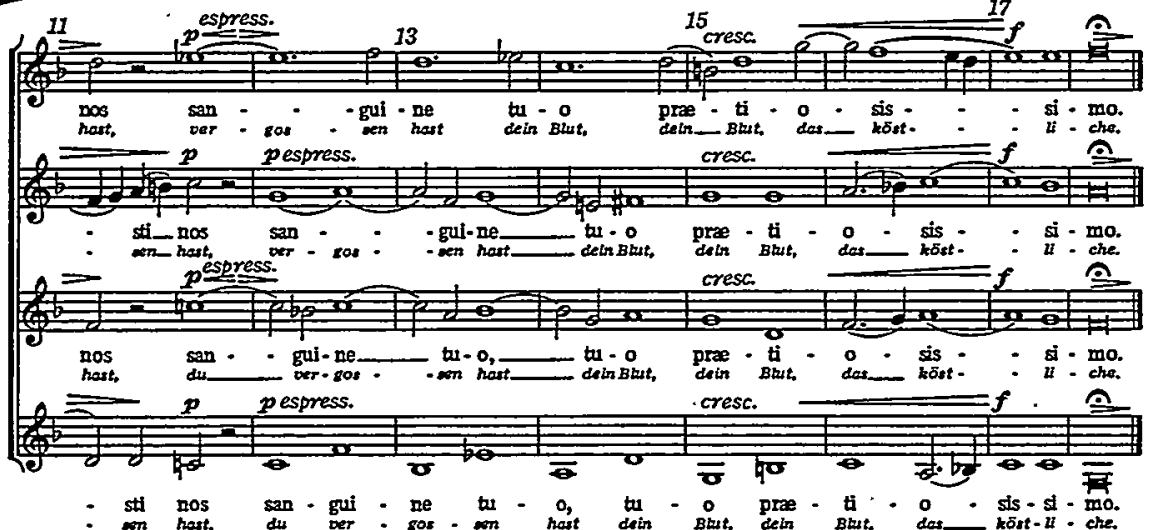




\section{APPENDIX B1: "JORDAN" (PUBLIC DOMAIN VERSION) \\ Jordan}
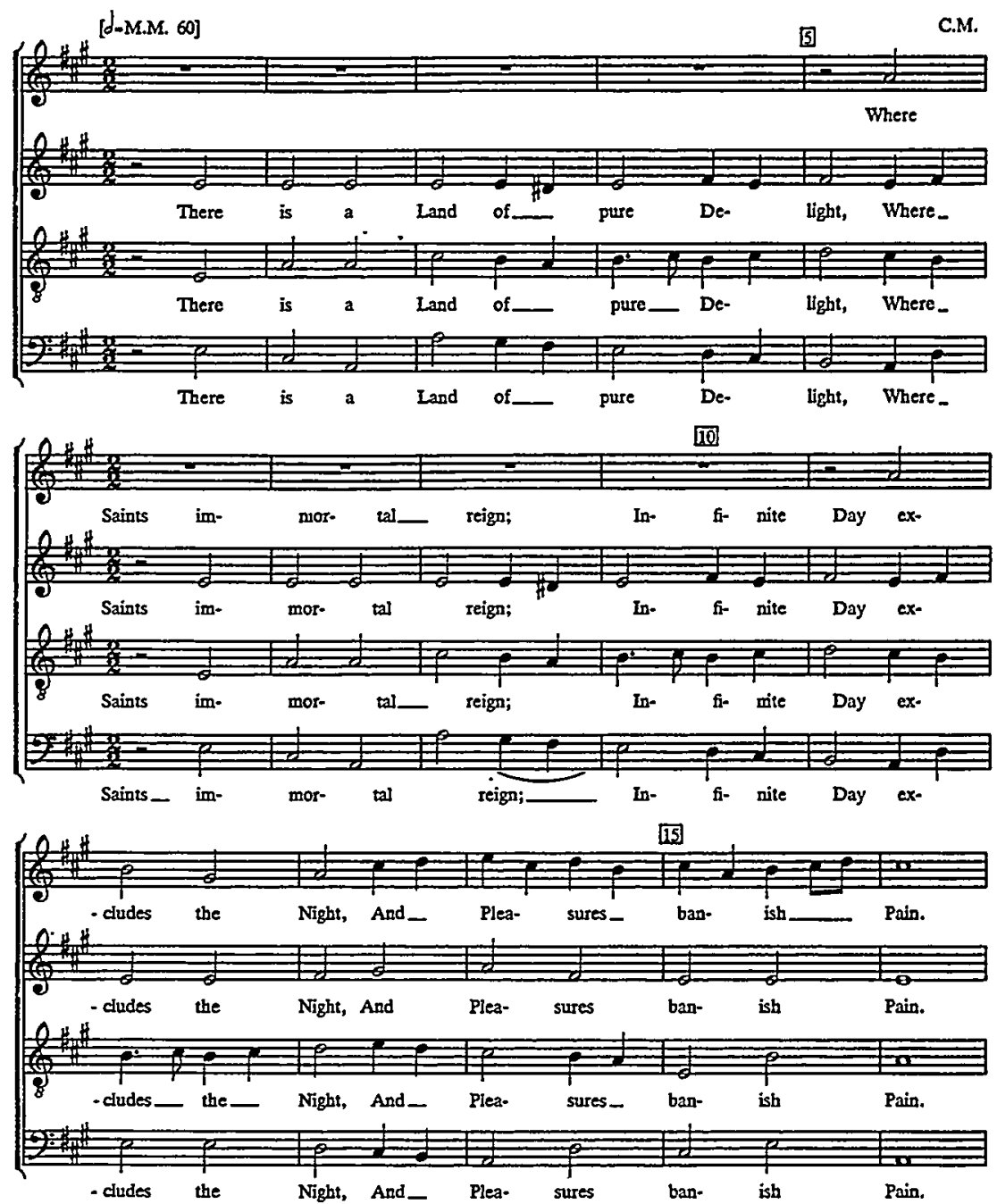

180 The Suffolk Harmony 

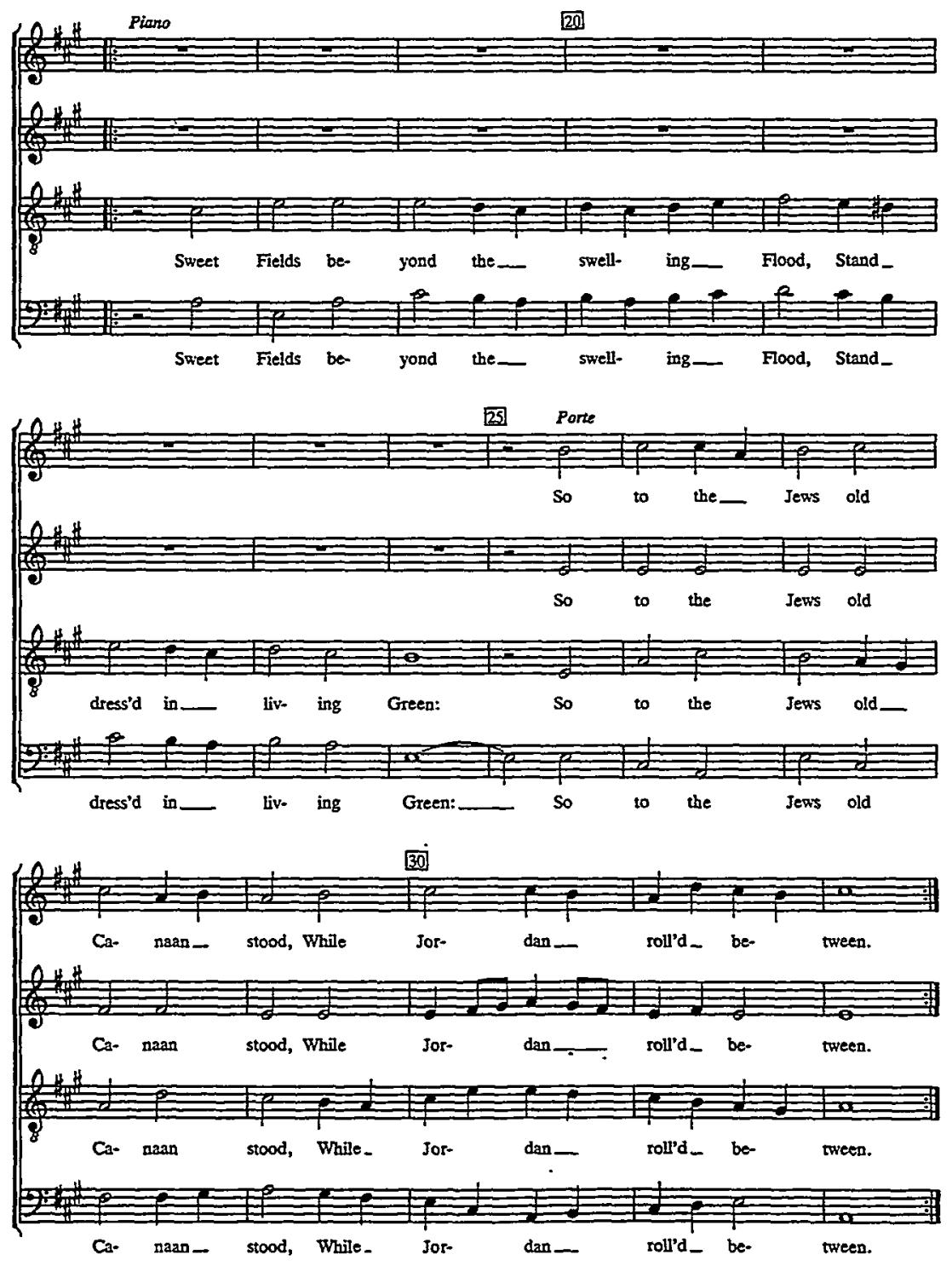

Jordan I8I 
APPENDIX B2: "JORDAN" ("COPYRIGHTED" VERSION)

\section{JORDAN}
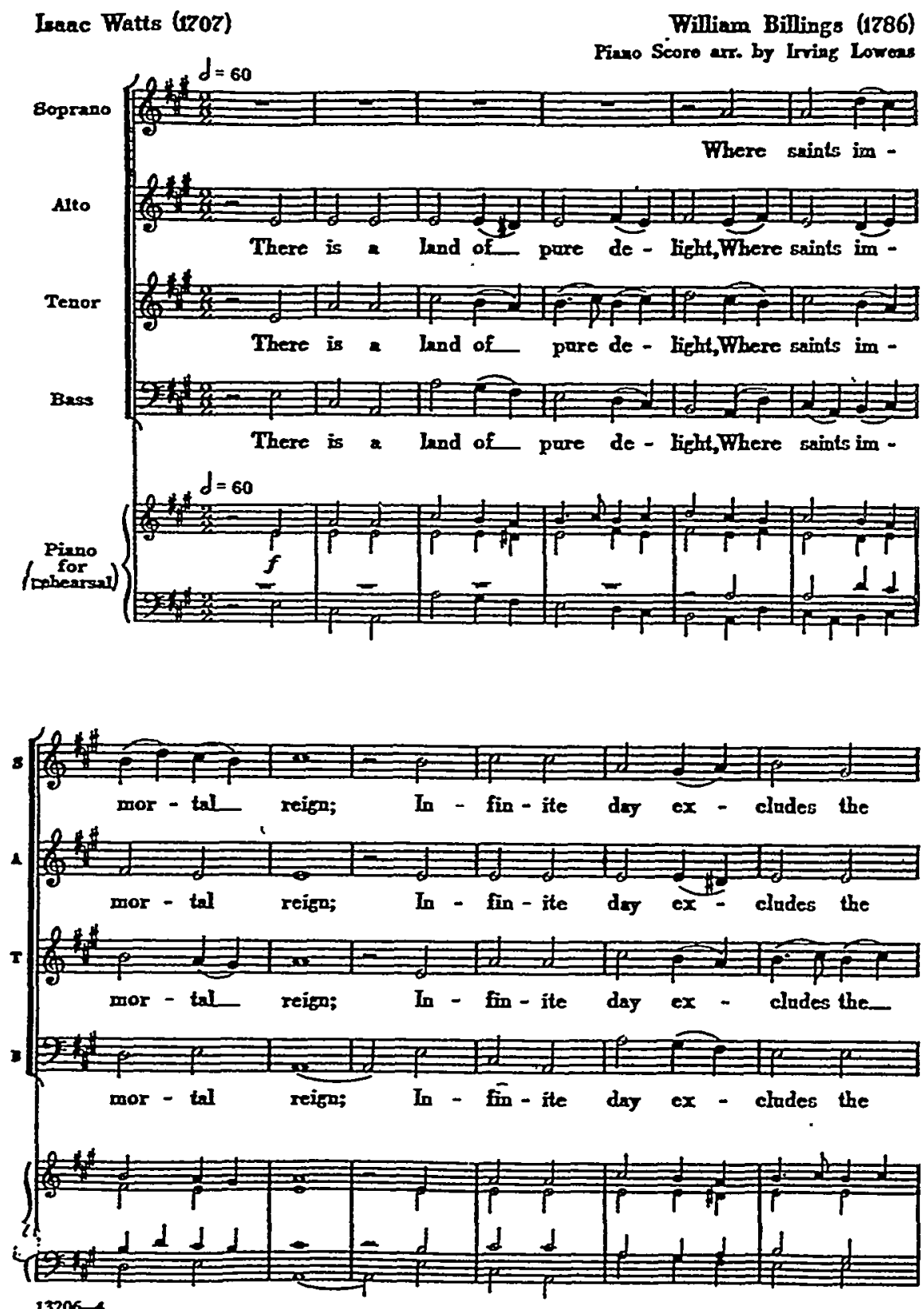

Coprright 1954, by Edward B. Xarks Kusic Corpotatlon 

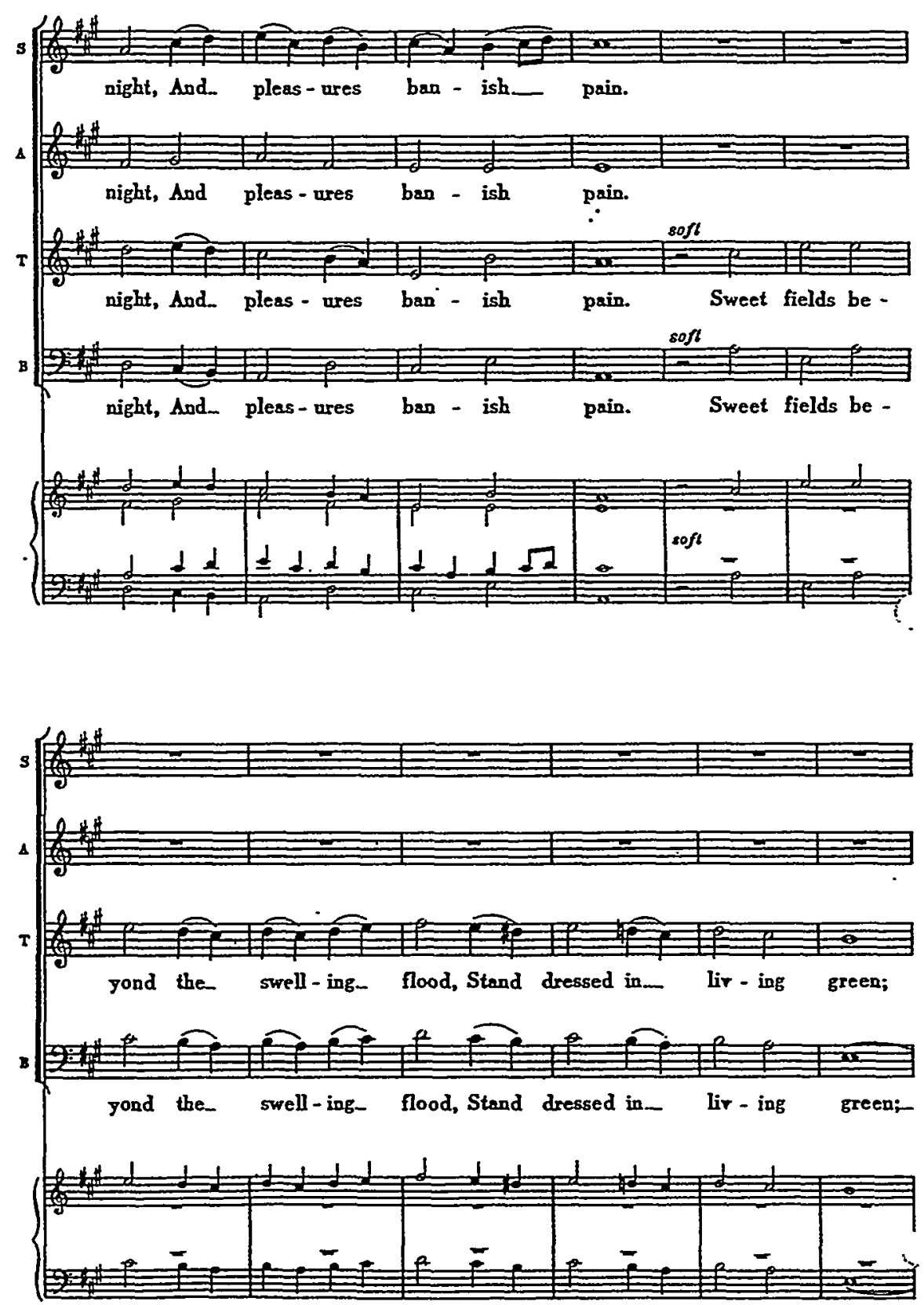

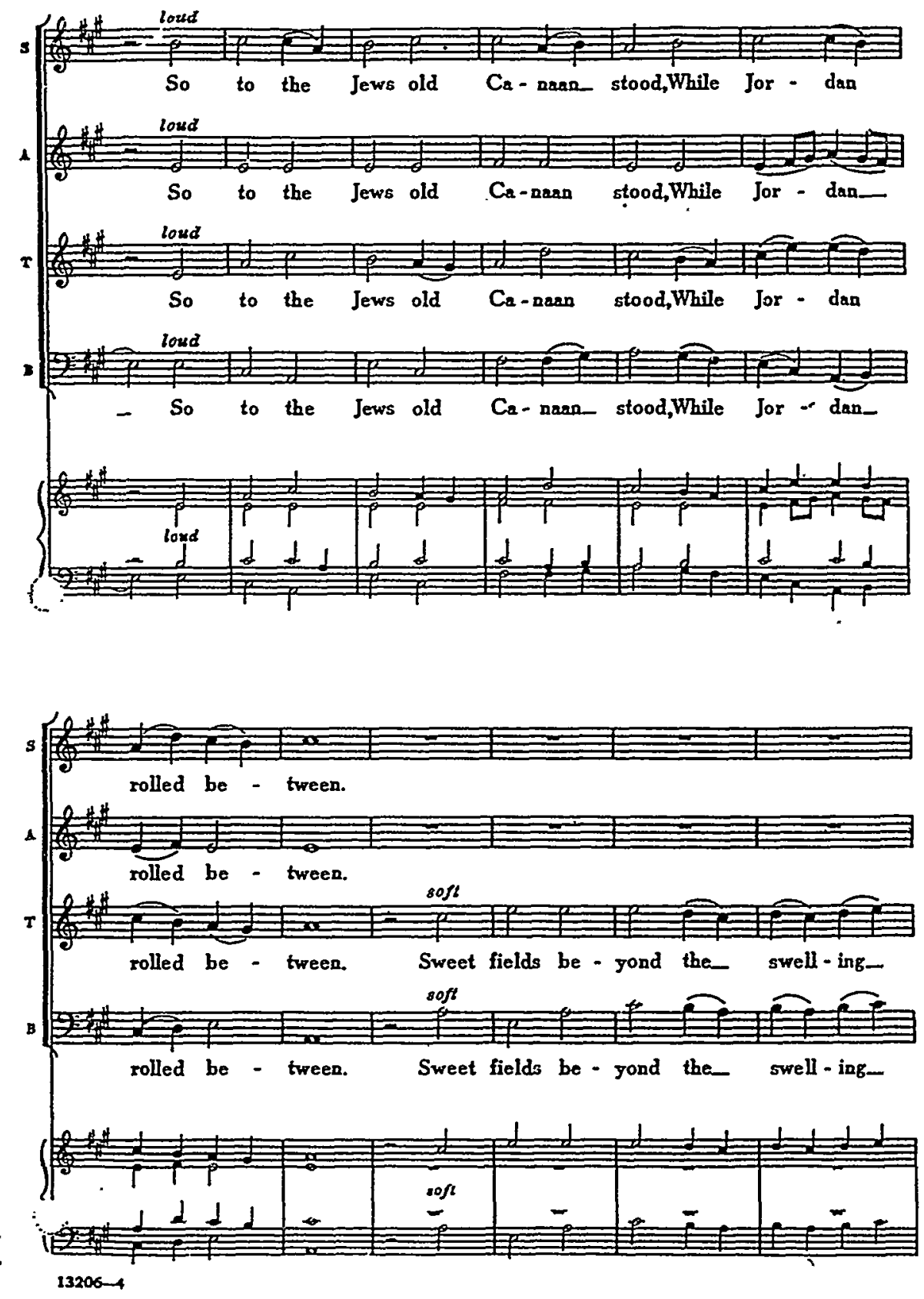
6
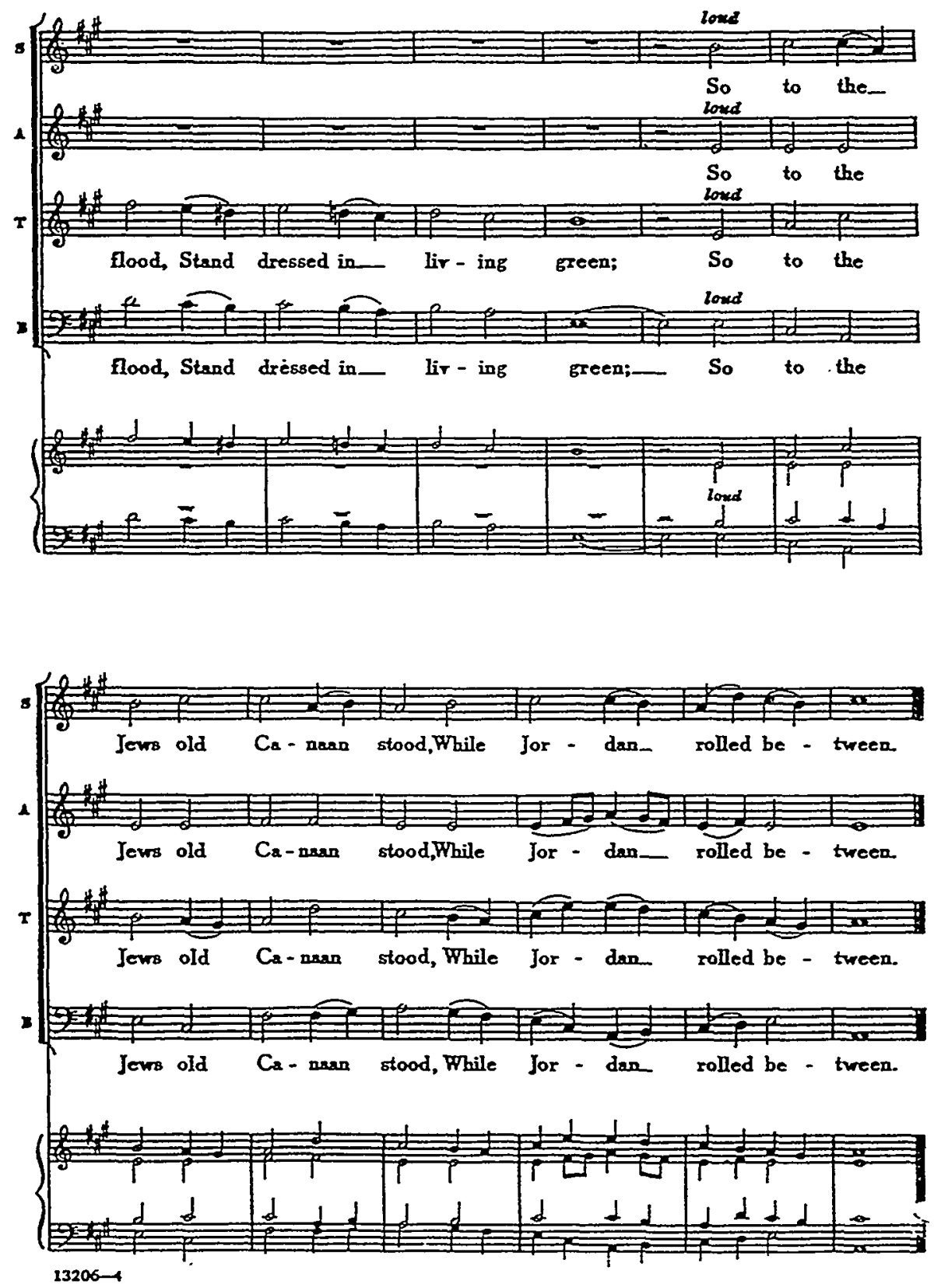

From prllian Billingis-Tho Sulfolk Bnrean (Bonton, 1786) 
APPENDIX C1: "HALlELUJAH, AMEN" (PUBLIC DOMAIN VERSION)
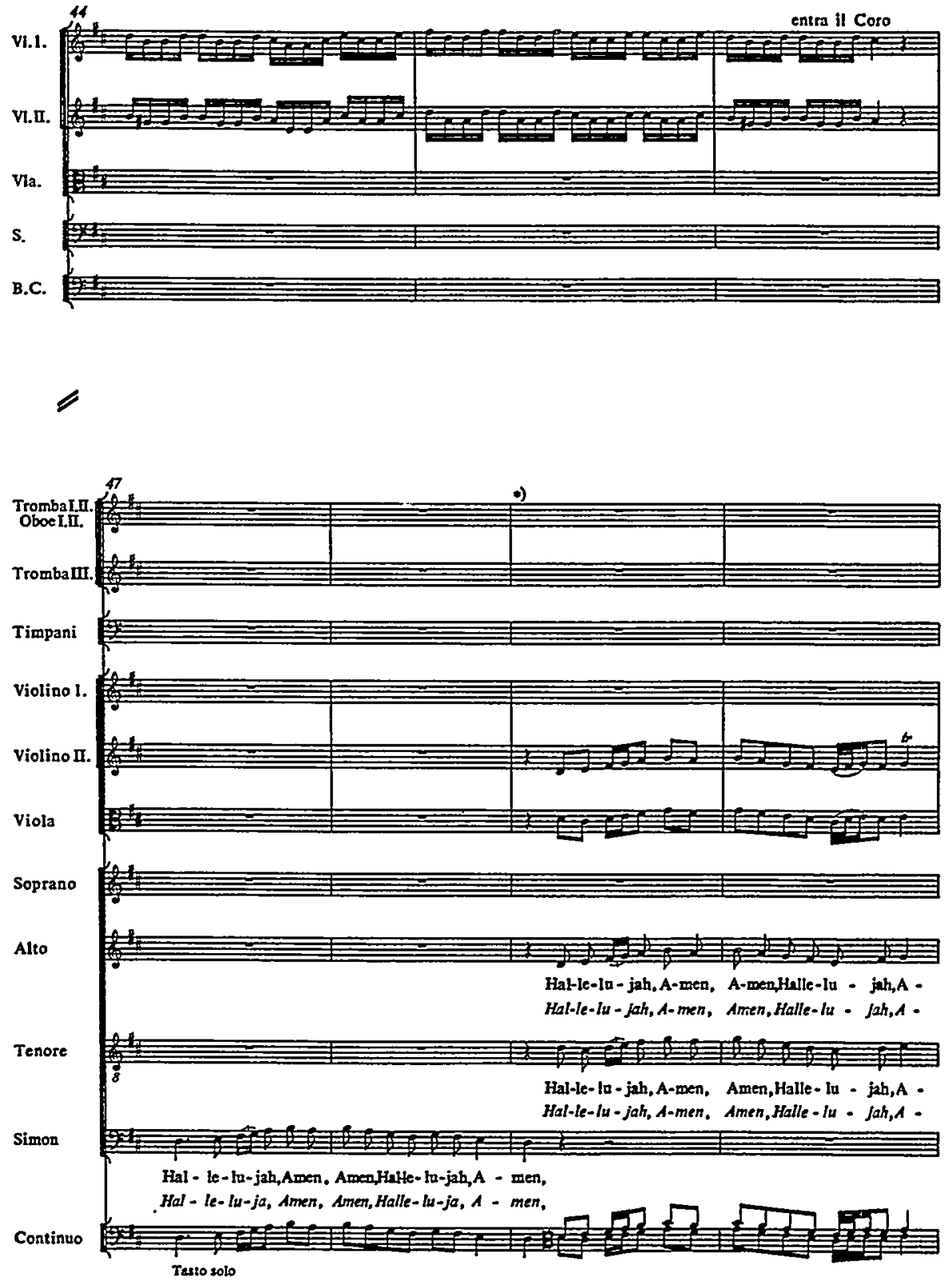
216
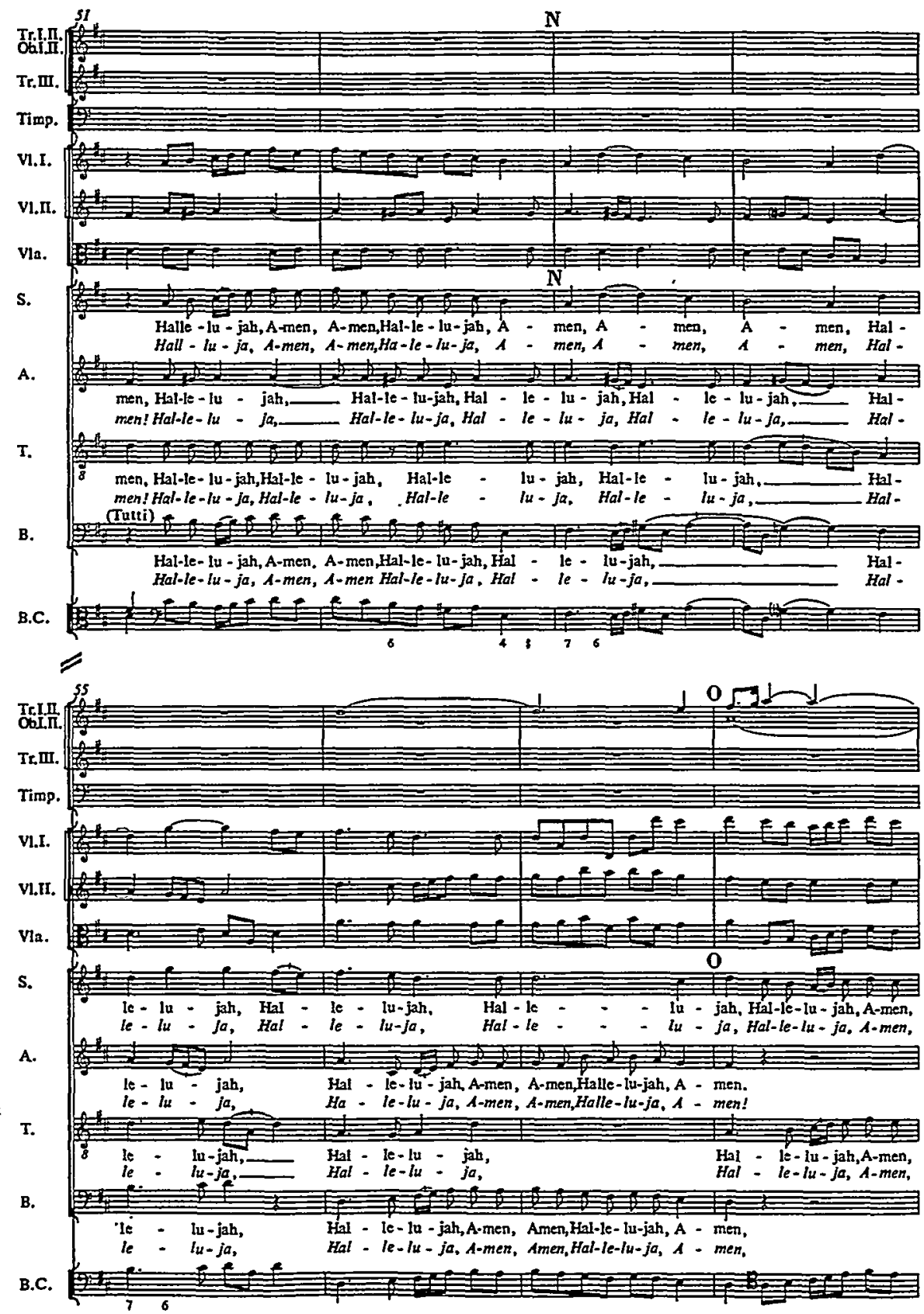

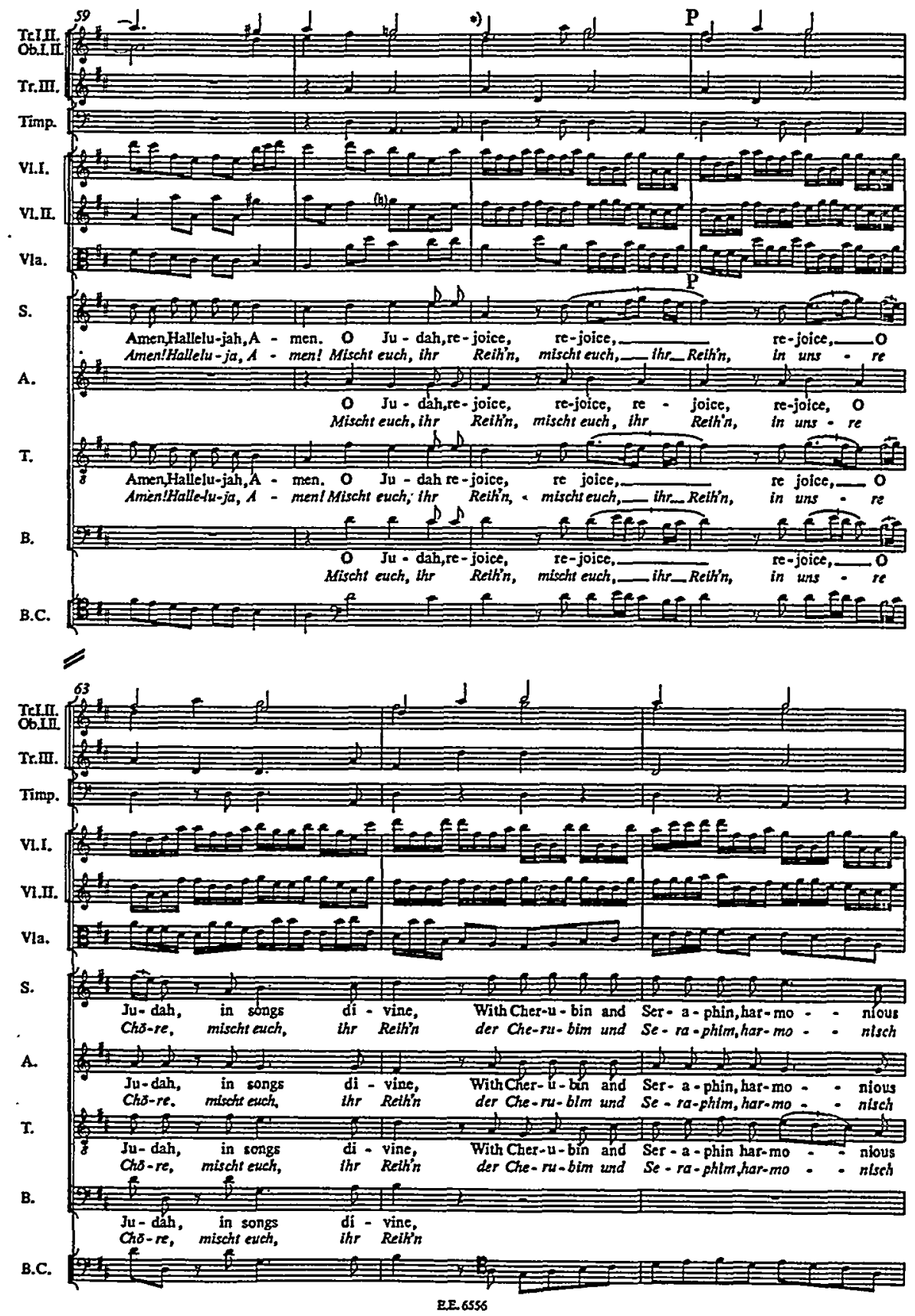
APPENDIX C2: "HALlELUJAH, AMEN" ("COPYRIGHTED" VERSION)

Edited by Norwood Birkle

GEORGE FRIDERIC HANDEI (1645-175e)
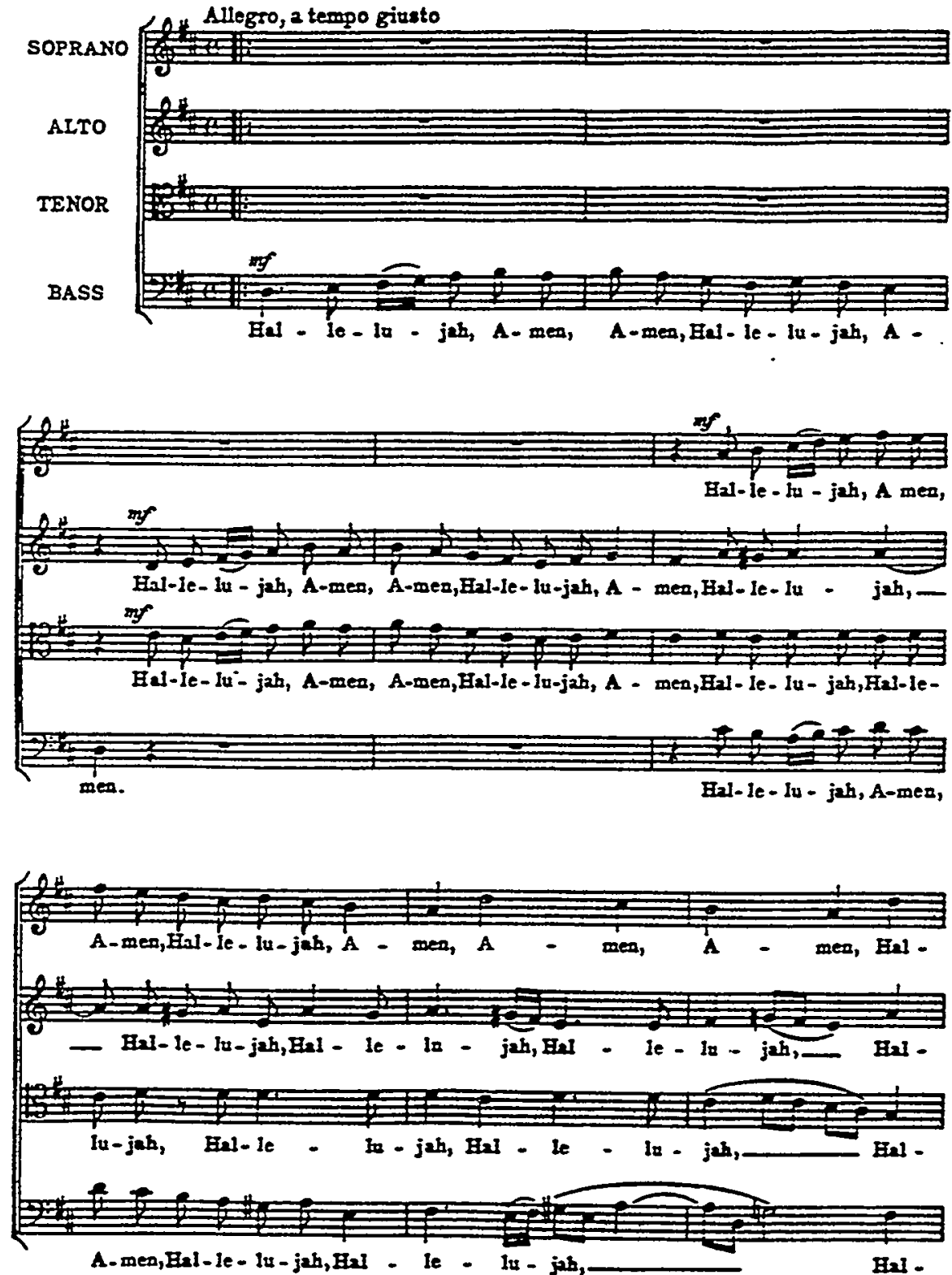

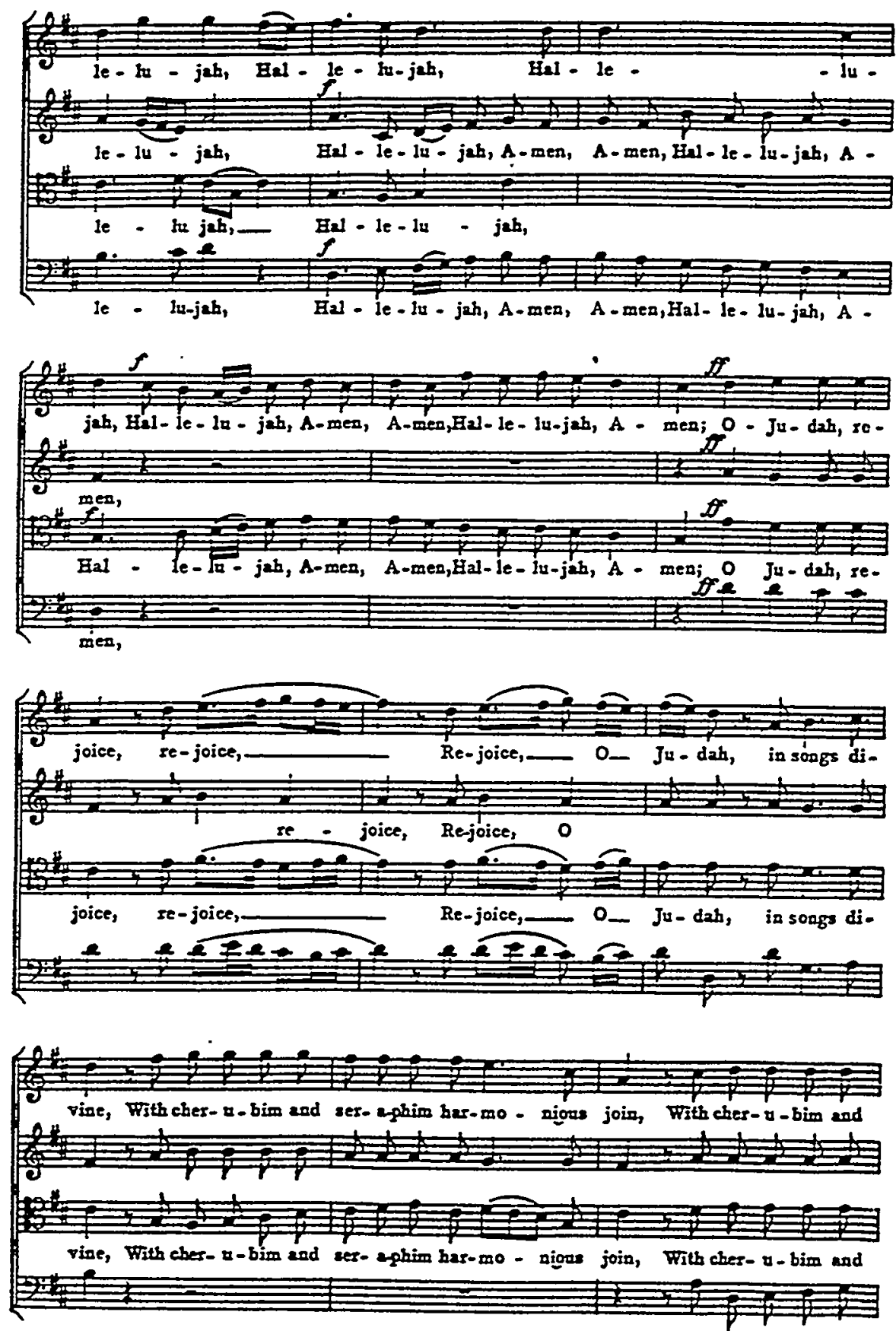